\title{
Flora da Bahia: Verbenaceae 1: Lantana
}

Tânia Regina dos Santos Silva* \& Carla Teixeira de Lima

Departamento de Ciências Biológicas, Universidade Estadual de Feira de Santana, Av. Transnordestina s/n, Novo Horizonte, 44.036-900, Feira de Santana, Bahia, Brasil.

\begin{abstract}
Resumo - O levantamento florístico do gênero Lantana (Verbenaceae) da Bahia, Brasil é apresentado como contribuição à Flora do Estado. Foram reconhecidas 14 espécies de Lantana. São apresentados chave de identificação, descrições, ilustrações, comentários taxonômicos e mapas de distribuição para as espécies no estado da Bahia.
\end{abstract}

Palavras-chave adicionais: florística, Lamiales, Nordeste, Semiárido, Taxonomia.

\begin{abstract}
Flora of Bahia: Verbenaceae: Lantana) - This account of Lantana L. (Verbenaceae) is a contribution to the ongoing Flora of Bahia project. A total of 14 species are recognized for the Bahia State, Brazil. An identification key, descriptions, illustrations, general notes and distribution maps of species in Bahia State are provided.
\end{abstract}

Additional key words: floristics, Lamiales, Northeast Brazil, semiarid region, Taxonomy.

\section{VERBENACEAE}

Ervas a arbustos, menos frequentemente árvores ou lianas, muitas vezes aromáticas. Folhas opostas, raramente verticiladas, simples, sem estípulas, margem serreada ou crenada. Inflorescências racemosas. Flores bissexuadas, zigomorfas, diclamídeas; cálice (2-)5-mero, gamossépalo, prefloração imbricada, acrescente, persistente ou caduco; corola 4- ou 5-mera, gamopétala, prefloração imbricada; estames 4, didínamos, raro 2, então com 2 estaminódios; ovário súpero, bicarpelar, 2-4-locular, divididos ou não por falso septo, estilete terminal, placentação ereta, óvulos 2 por carpelo. Frutos drupas ou esquizocarpos.

Verbenaceae possui distribuição pantropical, com maior diversidade na região neotropical, incluindo cerca de 36 gêneros e 1.000 espécies (Atkins 2004). Estudos filogenéticos corroboram o monofiletismo da família (Marx et al. 2010). No Brasil, está representada por cerca de 17 gêneros, sendo os mais representativos: Lippia L. (ca. 111 espécies), Lantana
L. (ca. 22 espécies) e Stachytarpheta Vahl (79 espécies) (Silva 1999; Atkins 2005; Souza \& Lorenzi 2008).

\section{Lantana L.}

Arbustos ou subarbustos. Folhas simples, decussadas ou 3-verticiladas. Inflorescências do tipo espigas, 1-3 por axila foliar, alongadas ou não após antese; brácteas foliáceas, verdes, raro vináceas, decussadas, caducas ou persistentes; cálice membranáceo, truncado, 2-5-lobado; corola com pétalas róseas, lilás, roxas, vermelhas, laranja, amarelas ou brancas, hipocrateriformes, limbo oblíquo, plano ou inclinado, sub-bilabiado, lábio posterior 2-lobado, anterior 3-lobado; estames 4, inclusos, didínamos; anteras amarelas, tecas elipsoides, 2-locular, sem glândulas, deiscência longitudinal; ovário 2-carpelar a 1-carpelar por aborto, 2-locular, lóculos 1-ovulados, fenda mediana entre os lóculos; estilete terminal; estigma oblíquo. Fruto drupa, vináceo, marrom ou negro, 1-pirenado, 2-locular, 2-seminado, mesocarpo suculento a seco, lacuna entre os lóculos de tamanho variado.

\section{Chave de identificação}

1. Inflorescências com brácteas iguais.

2. Ramos com acúleos. 3. L. camara

2'. Ramos sem acúleos.

3. Lâminas elípticas, nítidas; flores brancas 8. L. lucida

3'. Lâminas ovais a largo-ovais, foscas; flores lilás. 9. L. pohliana 1'. Inflorescências com brácteas desiguais.

4. Subarbustos. 6. L. gracilis

4'. Arbustos.

5. Inflorescência com 4 ou 5 brácteas externas maiores.

5 '. Inflorescência com 2 brácteas externas maiores.

6. Inflorescência menor ou igual ao tamanho das folhas; indumento seríceo.

7. Cálice 4-lobado; fruto marrom-claro. 4. L. canescens

7'. Cálice truncado; fruto vináceo. 7. L. hypoleuca

* Autora para correspondência: tanialantana@gmail.com

Editor responsável: Julio Lombardi

Submetido em: 5 set. 2011; publicação eletrônica: 26 dez. 2012 
6'. Inflorescência maior que o tamanho das folhas; indumento hirsuto ou estrigoso.

8. Indumento com tricomas glandulares. 12. L. tiliifolia

8 '. Indumento com tricomas filamentosos.

9. Lâmina foliar elíptica.

10. Brácteas externas obovais, ápice obtuso, 7-8 × 4-6 mm (mata)

10. L. radula

10'. Brácteas externas largo-ovais, ápice agudo, ca. $9 \times 7 \mathrm{~mm}$ (restinga)

14. L. undulata

9'. Lâmina foliar oboval-oblonga ou oval.

11. Lâmina foliar oboval-oblonga; brácteas internas elíptico-oblongas

11. L. salzmannii

11'. Lâmina foliar oval; brácteas internas ovais.

12. Corola $4-4,5 \mathrm{~mm}$ compr.

13. L. trifolia

12'. Corola 6-10 mm compr.

13. Folhas com ápice obtuso, base subtruncada a truncada; cálice bilabiada

2. L. caatingensis

13'. Folhas com ápice agudo, base atenuada a subcordada; cálice truncado. 5. L. fucata

1. Lantana achyranthifolia Desf., Tabl. École Bot. (ed. 3): 392. 1829.

Figuras 1 e 3.

Arbusto 0,5-2(-5) m alt.; ramos sem acúleos, eretos, glabrescentes. Folhas opostas, decussadas, coriáceas; pecíolo 5-18 mm compr.; lâmina 4,5-10 × 2-5,5 cm, elíptica a oval, fosca, ápice atenuado, margem serreada, não revoluta, base aguda, face adaxial escabra a estrigosa, abaxial estrigosa nas nervuras. Inflorescência 1 por axila, $6-16 \mathrm{~cm}$ compr.; pedúnculo 5,5-14,5 cm compr., seríceo; raque $0,5-1 \mathrm{~cm}$ compr., alongada na frutificação ( $1-1,5 \mathrm{~cm}$ compr.); brácteas verdes, seríceas, diferenciadas em 4 ou 5 externas, 2 primárias elípticas a lanceoladas, $8-10(-15) \times 4(-9) \mathrm{mm}, 2$ ou 3 secundárias, ca. $10 \times 4 \mathrm{~mm}$, ápice atenuado, as internas lanceoladas, ca. $7 \times 4 \mathrm{~mm}$, ápice atenuado, persistentes no fruto. Flores com cálice 1,5-2 mm compr., seríceo, acrescente no fruto, 2-lobado, lobos levemente arredondados; corola com tubo branco, ca. $8 \mathrm{~mm}$ compr., fauce amarela, puberulenta; filetes ca. $0,4 \mathrm{~mm}$ compr. Frutos ovoides, marrom-claros a alaranjados, pilosos, o mesocarpo tênue, 2,5$3,3 \times 2,3-3 \mathrm{~mm}$.

Espécie neotropical (Lopez-Palácios 1977; Troncoso \& Botta 1993). No Brasil, foi coletada na Bahia, Mato Grosso e Mato Grosso do Sul. F3: Caatinga. Floresce e frutifica em abril.

Material selecionado - Santa Maria da Vitória, 1327'00"S, $44^{\circ} 10^{\prime} 16^{\prime \prime} \mathrm{W}$, fev. 2000, L.P. Queiroz et al. 5970 (HUEFS); ib.,

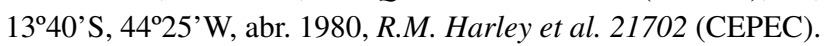

Lantana achyranthifolia caracteriza-se por apresentar espigas com 4 ou 5 brácteas externas maiores. O fruto é piloso, com mesocarpo inconspícuo e endocarpo desenvolvido. Assemelha-se a $L$. canescens pela presença de cálice bilobado, corola alva, mas diferencia-se por possuir inflorescências mais longas e mais brácteas.

2. Lantana caatingensis Moldenke, Phytologia 24(4): 298. 1972.

Figuras 2 e 3.

Arbusto 0,3-2,5 m alt.; ramos decussados, sem acúleos, glabrescentes. Folhas decussadas, membranáceas; pecíolo 5-15 mm compr.; lâmina $1-5 \times 0,7-3,5 \mathrm{~cm}$, oval, fosca, ápice obtuso, margem crenada, não revoluta, base aguda a truncada, face adaxial tomentosa, abaxial hirtela. Inflorescência 1 por axila, 1,5-3 cm compr.; pedúnculo 1-2 cm compr., tomentoso a glabrescente; raque $0,5-1 \mathrm{~cm}$ compr., alongada na frutificação (1-2 cm compr.); brácteas verdes, tomentosas a glabrescentes, diferenciadas em 2 externas, largo-ovais, 5$8 \times$ ca. $4 \mathrm{~mm}$, ápice obtuso, as internas elípticas, $4-5 \times$ ca. 2 $\mathrm{mm}$, ápice obtuso, persistentes no fruto. Flores com cálice 1-2 mm compr., tomentoso, acrescente no fruto, 2-lobado, lobos levemente arredondados; corola com tubo branco, róseo ou lilás, 5-6,5 mm compr., fauce amarela, puberulenta e glandulosa; filetes ca. 0,5 mm compr. Frutos largo-ovoides, vináceos, glabros, mesocarpo suculento, ca. 2,5 $\times 3 \mathrm{~mm}$.

Endêmica do Brasil: Pernambuco, Bahia e Minas Gerais. C/D8, D6, E6, F6: Campo rupestre, Cerrado e Caatinga. Floresce e frutifica de janeiro a março e de julho a novembro.

Material selecionado - Abaíra, jan. 1992, B. Stannard \& T. Silva 50845 (K, SPF); Andaraí, nov. 1986, P.A. Loizeau et al. 510 (CEPEC); Lençóis, jul. 1994, M.L. Guedes et al. PCD 292 (HUEFS); Morro do Chapéu, fev. 1971, H.S. Irwin et al. 30686 (isótipos NY, US); Mucugê, fev. 1994, S. Atkins et al. CFCR 14359 (ESA, SPF); Palmeiras, fev. 1994, S. Atkins et al. CFCR 14194 (ESA, SPF); Queimadas, $10^{\circ} 58^{\prime}$ 'S, 39² $36^{\prime} \mathrm{W}$, nov. 1986, L.P. Queiroz et al. 1145 b (HUEFS); Rio de Contas, mar. 1994, S. Atkins et al. CFCR 14789 (ESA, SPF). 0955'S, 40¹5'W, fev. 1974, R.M. Harley et al. 16344 (CEPEC, K, P).

Lantana caatingensis caracteriza-se por apresentar folhas com base subtruncada a truncada, margem crenada. $\mathrm{O}$ fruto possui mesocarpo suculento e presença de fenda entre os lóculos. A espécie assemelha-se a L. fucata por compartilharem a forma das brácteas externas (largo-ovais); porém, L. fucata possui corola maior e cálice truncado.

3. Lantana camara L., Sp. Pl. 2: 627. 1753.

= L. minasensis var. puberulenta Moldenke, Phytologia 25(4): 220. 1973. L. triplinervia var. puberulenta (Moldenke) Moldenke, Phytologia 28(4): 403. 1974. = L. morii Moldenke, Phytologia 41(8): 499. 1979.

Figuras 4 e 6. 


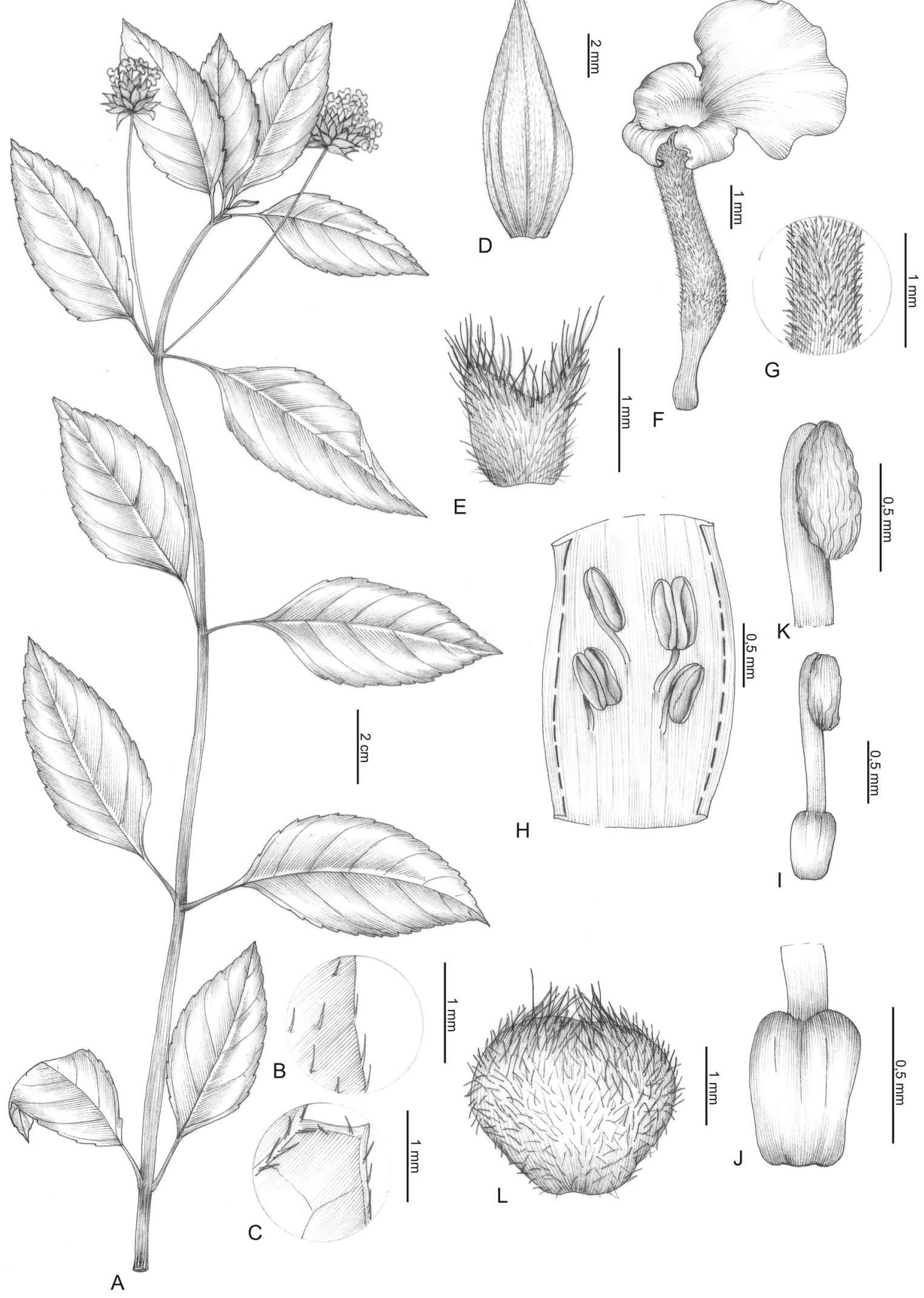

Figura 1. Lantana achyranthifolia: A- hábito; B- detalhe da lâmina, face adaxial; C- detalhe da lâmina, face abaxial; D- brácteas; E- cálice; F- corola; G- detalhe do indumento da corola; H- detalhe do androceu; I- gineceu; J- ovário; K- estigma; L- fruto (Queiroz 5970 e Harley 21702). 


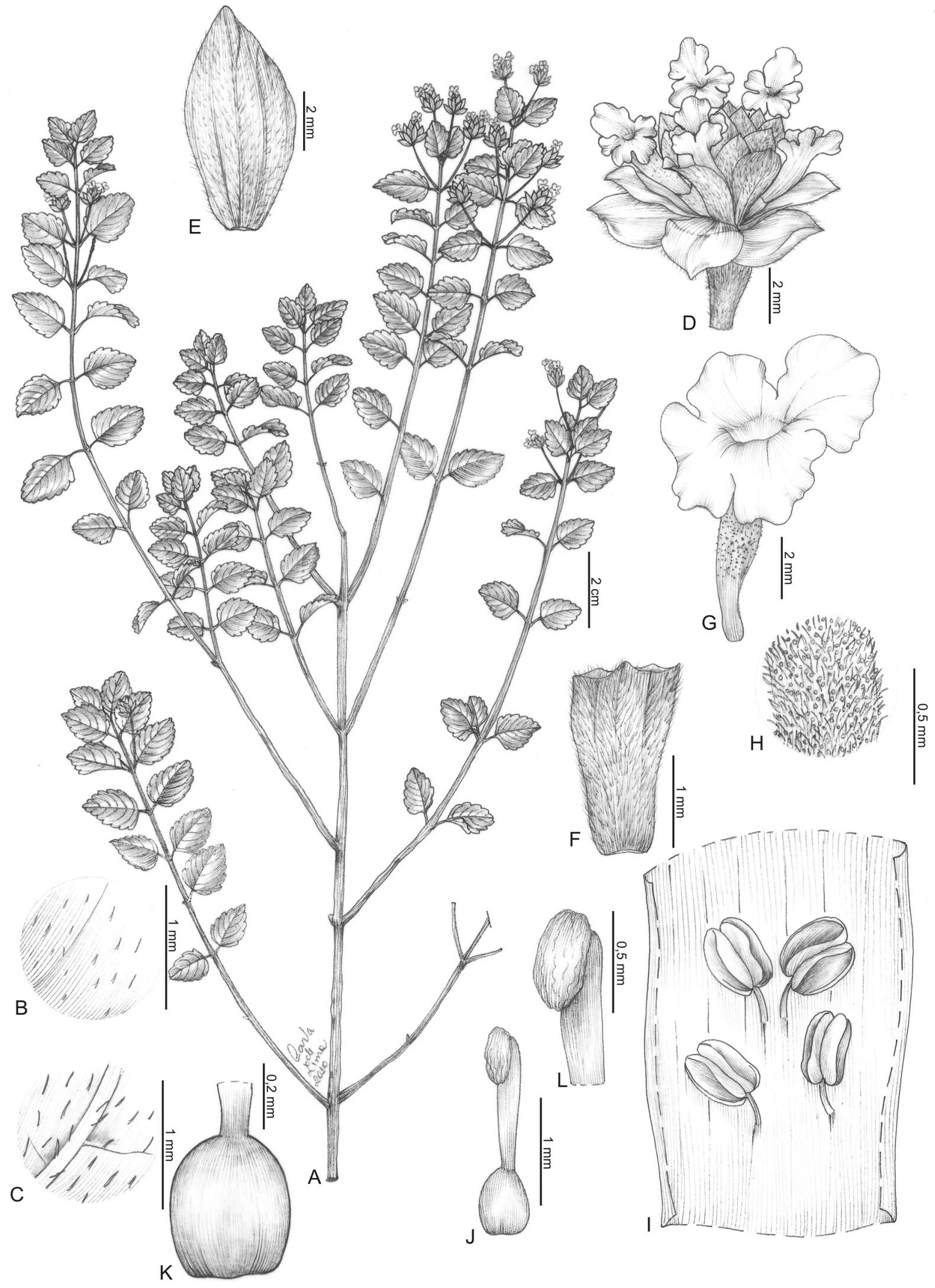

Figura 2. Lantana caatingensis: A- hábito; B- detalhe da lâmina, face adaxial; C- detalhe da lâmina, face abaxial; D- inflorescência; E- brácteas; Fcálice; G- corola; H- detalhe do indumento da corola; I- detalhe do androceu; J- gineceu; K- ovário; L- estigma (Queiroz 1145b). 


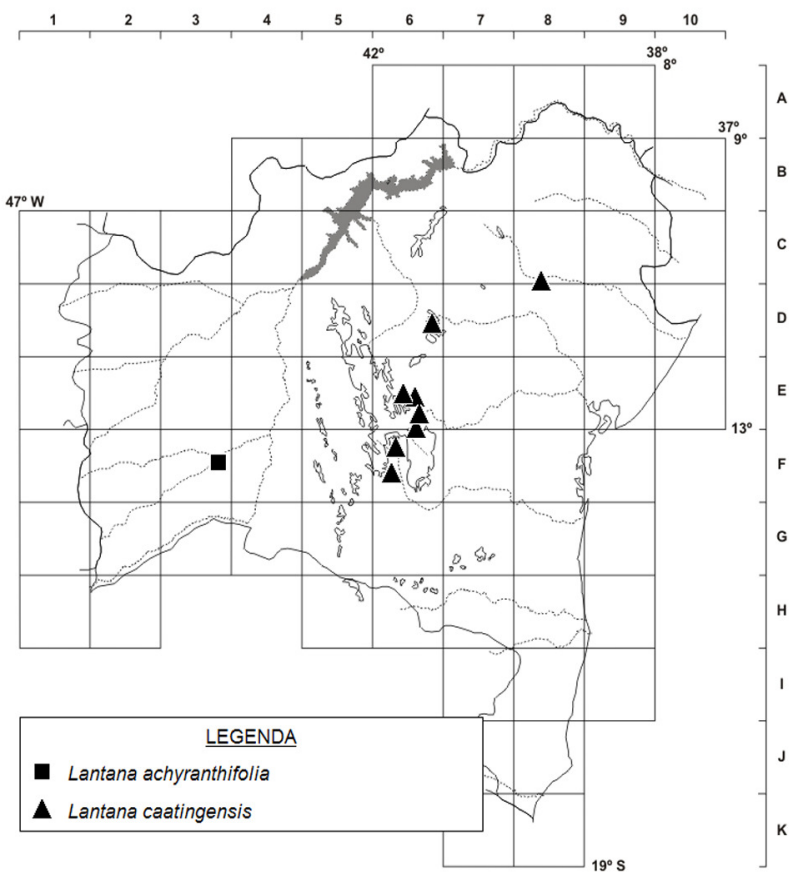

Figura 3. Mapa de distribuição de Lantana achyranthifolia e $L$. caatingensis no estado da Bahia.

Arbusto 1-3 m alt.; ramos eretos, raro escandentes, com acúleos, jovens hirsutos, adultos glabrescentes e/ou glandulares. Folhas decussadas, cartáceas; pecíolo 5-15 mm compr.; lâmina 2,5-10 × 1,2-6,5 cm, oval a elíptica, fosca, ápice agudo a atenuado, margem serreada, base cordada, obtusa, ou atenuada, não revoluta, hirsuta em ambas as faces. Inflorescência 1 ou 2 por axila, 3-7 cm compr.; pedúnculo 3,5-5,5 cm compr., tomentoso a glabrescente; raque 5-6 mm compr., alongada na frutificação $(1-2 \mathrm{~cm}$ compr.); brácteas verdes, tomentosas, internas e externas iguais, lanceoladas a oblongas, 5-8 × 1-1,5 mm, ápice atenuado, não persistentes no fruto. Flores com cálice 1,5-2,5 $\mathrm{mm}$ compr., tomentoso, acrescente no fruto, 2-lobado, lobos arredondados; corola com tubo amarelo, branco, laranja ou lilás, 7-10 mm compr., fauce amarela, puberulenta; filetes 0,8-1 mm compr. Frutos ovoides, vináceos, glabros, mesocarpo suculento, ca. $6 \times 4,5 \mathrm{~mm}$.

Espécie encontrada na América tropical (Sinha \& Sharma 1984). A9, B7, C/D2, D4/5, D5, D6, D7, E7 E8, E9, F3, F4, F6, F7, G3, G5, G6, G7, G8, G8/9, H8, I8, J8: ambientes alterados. Floresce e frutifica durante o ano todo.

Material selecionado - Abaíra, dez. 1991, D.J.N. Hind et al. H50278 (K, SPF); Anajé, maio. 1983, G. Hatschbach 46372 (MBM); Belmonte, mar. 1988, F.S. Santos 836 (CEPEC); Bom Jesus da Lapa, fev. 1991, G. Hatschbach 55152 (MBM); Brumado, fev. 1990, A.M. Miranda \& F. Esteves 108 (PEUFR); Cachoeira, jul. 1980, Grupo Pedra do Cavalo 401 (HUEFS); Caetité, fev. 1992, M.L. Guedes 2633 (ALCB) Camacan, jul. 1978, T.S. Santos \& L.A.M. Silva 3304 (holótipo NY, isótipo CEPEC); Camaçari, nov. 1982, L.R. Noblick et al. 2127 (HUEFS); Caraíbas, jan. 1978, J.R. Guillaumon 79 (SPSF); Caravelas, ago. 1961, A.P. Duarte 5934 (RB, SPF); Cocos, mar. 1972, W.R. Anderson et al.

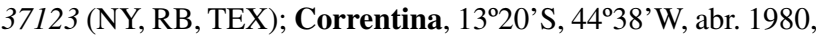
R.M. Harley et al. H21617 (CEPEC, IPA); Cruz das Almas, jan. 1981, G. Pinto 30/81 (CEPEC, MG); Dom Macedo Costa, jul. 1985, L.R. Noblick \& M. Lemos 3971 (HUEFS); Feira de Santana, nov. 1986, L.P. Queiroz \& M. Lemos 1027 (HUEFS); Formosa do Rio Preto, abr. 1989, J.M. Feldili 185 (IBGE); Ibipeba, 11²43'S, $42^{\circ} 04^{\prime} \mathrm{W}$, abr. 1984, O.A. Salgado \& H.P. Bautista 346 (IPA, MBM); Ilhéus, out. 1995, L.A.M. Silva et al. 3269 (CEPEC); Ipacaetá, $12^{\circ} 20^{\prime} \mathrm{S}, 39^{\circ} 17^{\prime} \mathrm{W}$, ago. 1985, L.R. Noblick \& C.G. Lobo 4346 (HUEFS, K, MBM); Ipirá, jul. 1984, E.L.P.G. Oliveira 731 (HUEFS); Itaberaba, nov. 1982, B.C. Bastos 96 (K); Itacaré, mar. 1974, R.M. Harley et al. H17478 (CEPEC, IPA). Ituaçu, dez. 1983, E.P. Gouveia 65/83 (ALCB, K); Jacobina, J. Blanchet 138 (BM); Jequié, out. 1983, A.M. Carvalho 1929 (CEPEC); Juazeiro, 1914, P.V. Lutzelburg 767 (M, R); Maracás, 13²0'S, 40²8'W, mar. 1988, L.A.M. Silva \& H.S. Brito 827 (CEPEC); Morpará, 114'S, $42^{\circ} 59^{\prime}$ W, O.A. Salgado \& H.P. Bautista 312 (IPA, MBM); Morro do Chapéu, mar. 1996, F.R. Salimena-Pires et al. 2303 (K); Mundo Novo, fev. 1970, A.L. Costa s.n. (ALCB 3577); Porto Seguro, jun. 1967, J.P.L. Sobrinho \& A. Castellanos 1500 (CEPEC); Rodelas, jan. 1987, G.O. Mattos et al. 70 (HBR); Salvador, Ilha de Itaparica, maio 1986, L.L. Andrade s.n. (ALCB 15933); Santa Cruz Cabrália, ago. 1980, O. Santos Filho 8 (CEPEC); Santa Cruz da Vitória, jan. 1969, J. Almeida 348 (CEPEC); Santa Terezinha, maio 1984, L. Noblick et al. 3227 (MBM); Santo Amaro, nov. 1959, A.L. Costa s.n. (ALCB 3580); Una, out. 1987, E.B. Santos \& M.C. Alves 97 (CEPEC, K). 1830, M. Salzmann 426 (G); Vitória da Conquista, fev. 1992, A.M. Carvalho et al. 3683 (CEPEC, HUEFS, MBM).

Lantana camara caracteriza-se por possuir ramos aculeados, indumento composto de tricomas filamentosos e/ou glandulares; as espigas possuem brácteas iguais, caducas na frutificação; e o mesocarpo é suculento. Compartilha a presença de acúleos com $L$. cujabensis Schauer, que não ocorre na Bahia, e L. viscosa Pohl ex Schauer, da qual se diferencia por apresentar brácteas ovais.

4. Lantana canescens Kunth in Humboldt, Bonpland \& Kunth, Nov. Gen. Sp. (quarto ed.) 2: 209. 1818.

Figuras 5 e 6.

Arbusto 1-2 $\mathrm{m}$ alt.; ramos eretos, raro escandente, sem acúleos, glabrescentes e/ou glandulares. Folhas decussadas, cartáceas a membranáceas; pecíolo 5-15 mm compr.; lâmina 4-10 × 1,5-4,5 cm, oval a elíptica, canescente, ápice agudo, margem crenada a serreada, base atenuada, não revoluta, face adaxial serícea, abaxial tomentosa. Inflorescência $1 \mathrm{ou}$ 2 por axila, 2-6 $\mathrm{cm}$ compr.; pedúnculo 3,5-5,5 $\mathrm{cm}$ compr., seríceo; raque ca. $5 \mathrm{~mm}$ compr., alongada na frutificação (1-2 cm compr.); brácteas verdes, seríceas, diferenciadas em 2 externas largo-ovais, ca. 6,5 × $30 \mathrm{~mm}$, ápice agudo, as internas ovais, ca. $5 \times 2,5 \mathrm{~mm}$, ápice agudo, não persistentes no fruto. Flores com cálice ca. $1 \mathrm{~mm}$ compr., seríceo, acrescente no fruto, 4-lobado, lobos obtusos; corola com tubo branco, raro lilás, ca. $7 \mathrm{~mm}$ compr., fauce amarela, puberulenta; filetes ca. 0,3 mm compr. Frutos ovoides, mar- 


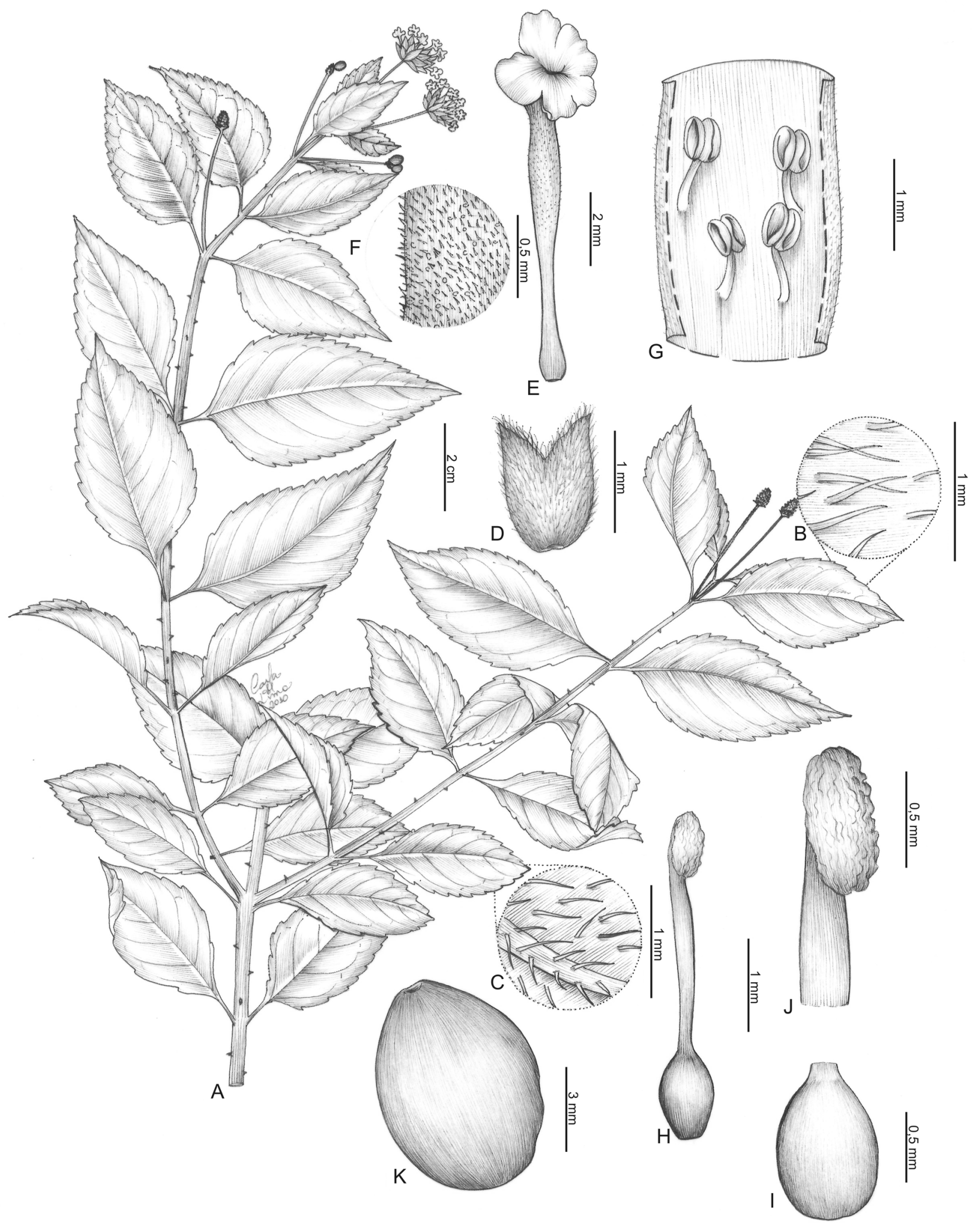

Figura 4. Lantana camara: A- hábito; B- detalhe da lâmina, face adaxial; C- detalhe da lâmina, face abaxial; D- cálice; E- corola; F- detalhe do indumento da corola; G- detalhe do androceu; H- gineceu; I- ovário; J- estigma; K- fruto (Salimena-Pires 2303). 


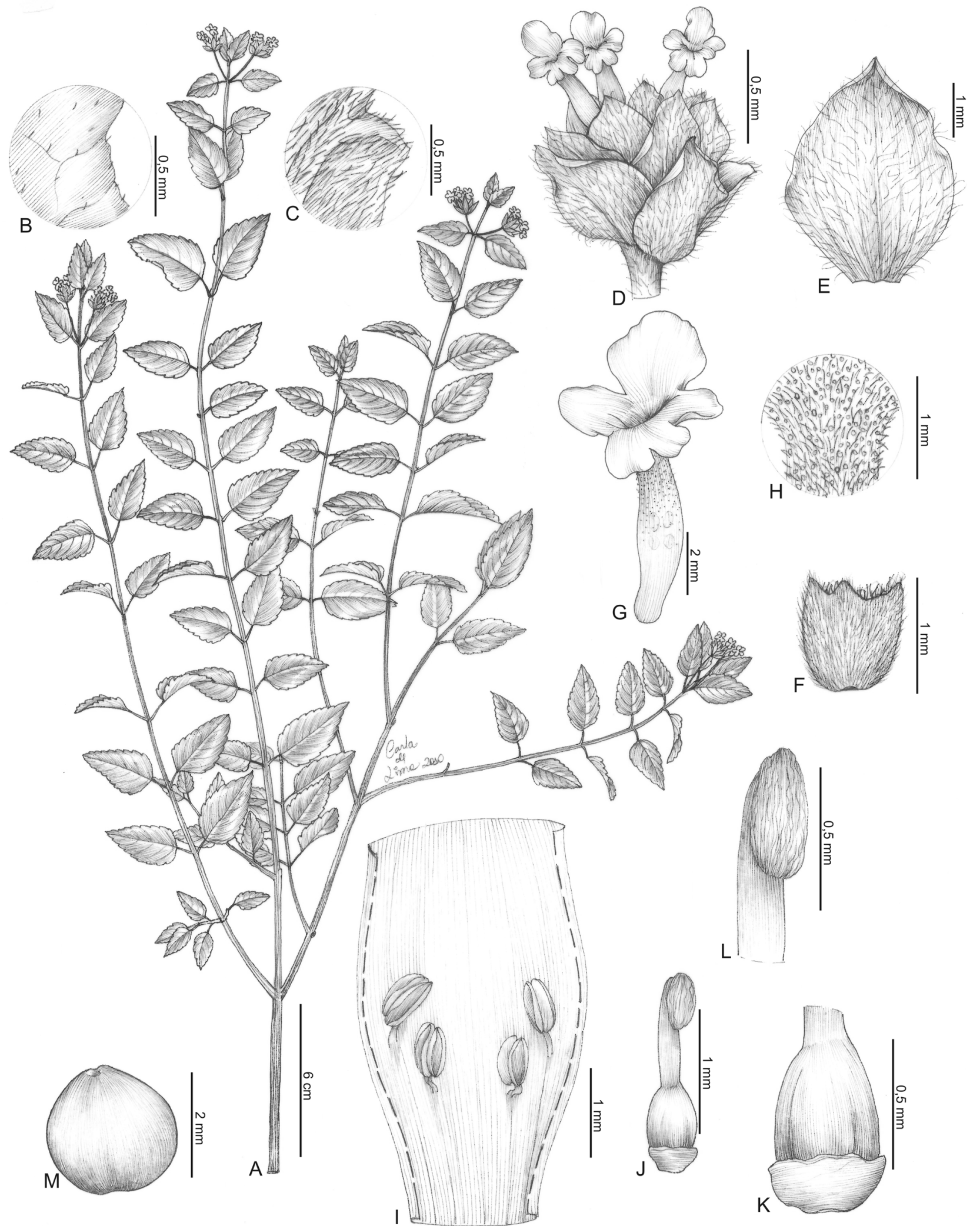

Figura 5. Lantana canescens: A- hábito; B- detalhe da lâmina, face adaxial; C- detalhe da lâmina, face abaxial; D- inflorescência; E- brácteas; F- cálice; G- corola; H- detalhe do indumento da corola; I- detalhe do androceu; J- gineceu; K- ovário; L- estigma; M- fruto (França 1625 e Melo 207). 


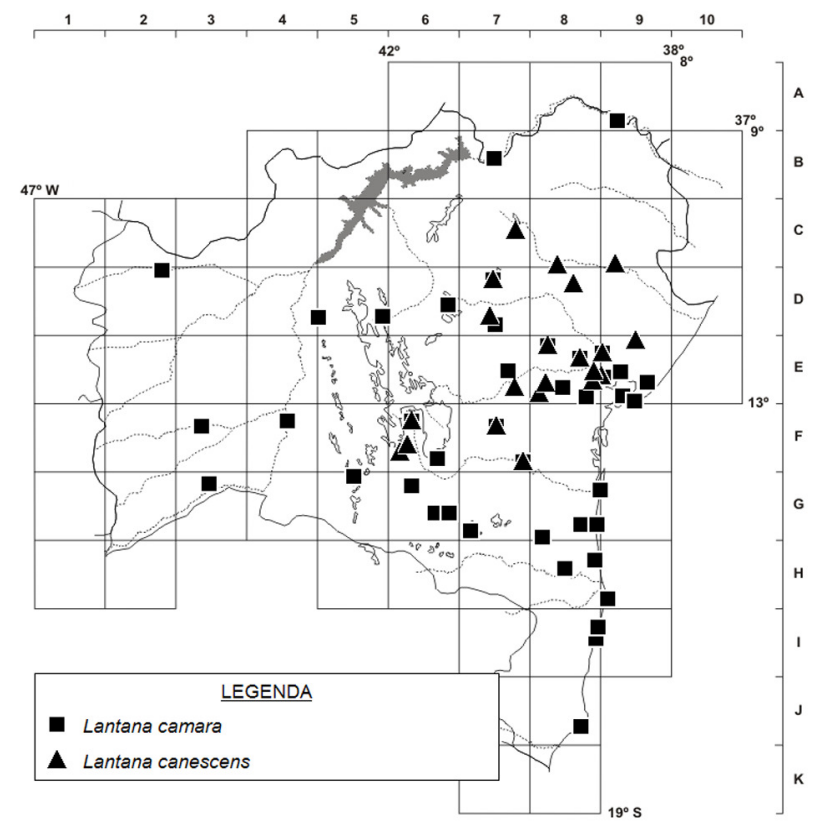

Figura 6. Mapa de distribuição de Lantana camara e L. canescens no estado da Bahia.

rom-claros, glabros, mesocarpo tênue, ca. 2,5 × 2,7 mm.

Espécie neotropical. C7, C/D8, C/D9, D7, D8, E7, E8, E8/9, E9, F6, F7: em beira de matas. Floresce e frutifica de fevereiro a agosto.

Material selecionado - Abaíra, fev. 1994, S. Atkins et al. CFCR 14641 (SPF); Aramari, jul. 1981, B.C. Bastos 126 (IBGE); Cachoeira, 3905'W, $12^{\circ} 32^{\prime} \mathrm{S}$, jun. 1980, Grupo Pedra do Cavalo 258 (ALCB, CEPEC, HUEFS, RB); Cruz das Almas, jul. 1964, E. Santos \& J.C. Sacco 1973 (R); Feira de Santana, mar. 1984, L.R. Noblick 3105 (ALCB, HUEFS); Iaçu, fev. 1997, 1245'S, $38^{\circ} 51^{\prime} \mathrm{W}$, E. Melo et al. 2075 (HUEFS); Ipecaetá, 12²0'S, $39^{\circ} 17^{\prime}$ W, ago. 1985, L.R. Noblick \& C.G. Lobo 4350 (CEPEC, HUEFS); Ipirá, jul. 1984, B.C. Bastos 486 (ALCB, HUEFS); Itatim, $12^{\circ} 42^{\prime} \mathrm{S}, 39^{\circ} 46^{\prime} \mathrm{W}$, jun. 1996, F. França et al. 1625 (HUEFS); Jacobina, abr. 1996, M.L. Guedes et al. 2808 (K); Jequié, maio 1979, S. Mori \& T.S. Santos 11848 (CEPEC, NY, RB); Livramento, $41^{\circ} 50^{\prime} \mathrm{W}, 1^{\circ} 43^{\prime}$ 'S, abr. 1991, G.P. Lewis \& S.M.M. Andrade 1968 (CEPEC, K); Maracás, 1906, E. Ule 6993b (K); Milagres, mar. 1977, R.M. Harley et al. 19465 (CEPEC, NY); Piritiba, 1143'S, 40³3'W, maio 1980, L.R. Noblick 1838 (ALCB, HUEFS); Queimadas, nov. 1986, L.P. Queiroz et al. 1145 a (HUEFS, K); Rio de Contas, 133' ' S, 41 ${ }^{\circ} 43^{\prime}$ 'W, nov. 1988, R.M. Harley et al. 26441 (CEPEC, K, SPF); Santaluz, jul. 1976, A. Rocha s.n. (IAC 23269); São Félix, 12³6'S, 3859'W, dez. 1992, M.M. Arbo et al. 5540 (SPF); Senhor do Bonfim, jan. 1979, J. Döbereiner \& C. Tokarnia 1461 (CEPEC); Tucano, mar. 1992, A.M. Carvalho \& N. Hind 3880 (CEPEC, HUEFS, MBM).

Lantana canescens caracteriza-se por apresentar indumento canescente, fruto marrom com mesocarpo pouco desenvolvido.

5. Lantana fucata Lindl., Bot. Reg. 10: tab. 798. 1824. Figuras 7 e 9.
Arbusto 0,7-2 m alt.; ramos eretos, decumbentes, raro escandentes, sem acúleos, tomentosos a glabrescentes. Folhas decussadas, membranáceas; pecíolo 2-15 mm compr.; lâmina 1,5-6,5 × 0,7-3,5 cm, elíptica, fosca, ápice agudo a atenuado, margem serreada, base subcordada a atenuada, levemente revoluta a não revoluta, face adaxial hirtela, abaxial tomentosa. Inflorescência 1 por axila, 1-2 cm compr.; pedúnculo 1-8,5 cm compr., seríceo; raque 0,5-2 cm compr., alongada na frutificação (1-3 cm compr.); brácteas verdes, seríceas, diferenciadas em 2 externas largo-ovais, 6,5-10 × 5-6 mm, ápice agudo a atenuado, as internas ovais, ca. 5,5-6 × 2,5-3 mm, ápice atenuado, persistentes no fruto. Flores com cálice 1-2 mm compr., seríceo, acrescente no fruto, inconspicuamente 4- ou 5-lobado, lobos obtusos; corola com tubo lilás, 6-10 mm compr., fauce amarela, puberulenta; filetes ca. 0,5 mm compr. Frutos largo-ovoides, vináceos, glabros, mesocarpo suculento, ca. 2,5 $\times 4 \mathrm{~mm}$.

Espécie encontrada na América tropical e subtropical. C7, D/E3, D5, D8/9, D9, E6, E8, E9, F5, F6, F7, G6, G7: ruderal. Floresce e frutifica de março e dezembro.

Material selecionado - Abaíra, nov. 1993, F. França et al. 894 (HUEFS); Bonfim, maio 1918, H. M.Curran 212 (NY); Brumado, abr. 1984, J.E. Brazão 307 (RB); Caetité, 1346'S, 42²2'W, mar. 1994, V.C. Souza et al. 5405 (K, SPF) ; Camaçari, dez. 1982, L.R. Noblick et al. 2244 (HUEFS) ; Candeias, out. 1983, G.C.P. Pinto 268/83 (ALCB, HRB); Cotegipe, out. 1986, M.L. Guedes \& L.B. Silva 1177 (ALCB); Cruz das Almas, jul. 1972, B.M. Costa s.n. (ALCB 6989); Igaraporã, 1346'S, 4241'W, abr. 1980, R.M. Harley et al. 21360 (CEPEC, K, NY); Itiruçu, ago. 1975, P. Souza s.n. (ALCB 10753); Jaguaquara, abr. 1942, P.T. Mendes s.n. (IAC 4928, SP, SPF); Lençóis, nov. 1994, E. Melo et al. 1306 (SPF); Maracás, nov. 1986, A. Chautems et al. $150 b$ (CEPEC); Olindina, ago. 1993, A. Fernandes \& E.J.A. Matos s.n. (EAC, SPF 113034); Salvador, s.d., C.M.O. Longa 10 (ALCB); Serrinha, set. 1937, P. Silva 48 (SP); Uibaí, 11²0'S, 4208'W, mar. 1996, A.A. Conceição et al. PCD 2474 (ALCB, SPF); Vitória da Conquista, abr. 1984, J.C.A. Lima \& C. Oliveira 97 (HRB).

Lantana fucata caracteriza-se por apresentar duas brácteas externas largo-ovais com ápices agudos ou atenuados.

6. Lantana gracilis T.R.S.Silva, Darwiniana 40: 59. 2002. Lippia bahiensis Moldenke (non Lantana bahiensis

Turcz.), Phytologia 31(2): 229. 1975;

Figuras 8 e 9.

Subarbusto 10-20 cm alt.; ramos eretos ou prostrados, sem acúleos, hirsutos. Folhas decussadas, membranáceas; pecíolo 2-4 mm compr.; lâmina 6-9 × 4-6 mm, elíptica, fosca, ápice agudo a atenuado, margem serreada, base obtusa, levemente revoluta, face adaxial estrigosa, a abaxial estrigosa apenas nas nervuras. Inflorescência 1 por axila, 2-3 cm compr.; pedúnculo 1,5-2,5 cm compr., seríceo; raque 5-6 mm compr., alongada na frutificação (6-7 mm compr.); brácteas verdes, seríceas, diferenciadas em 2 externas largo-ovais, ca. $5 \times 3 \mathrm{~mm}$, ápice agudo, as internas ovais, 4,5- 


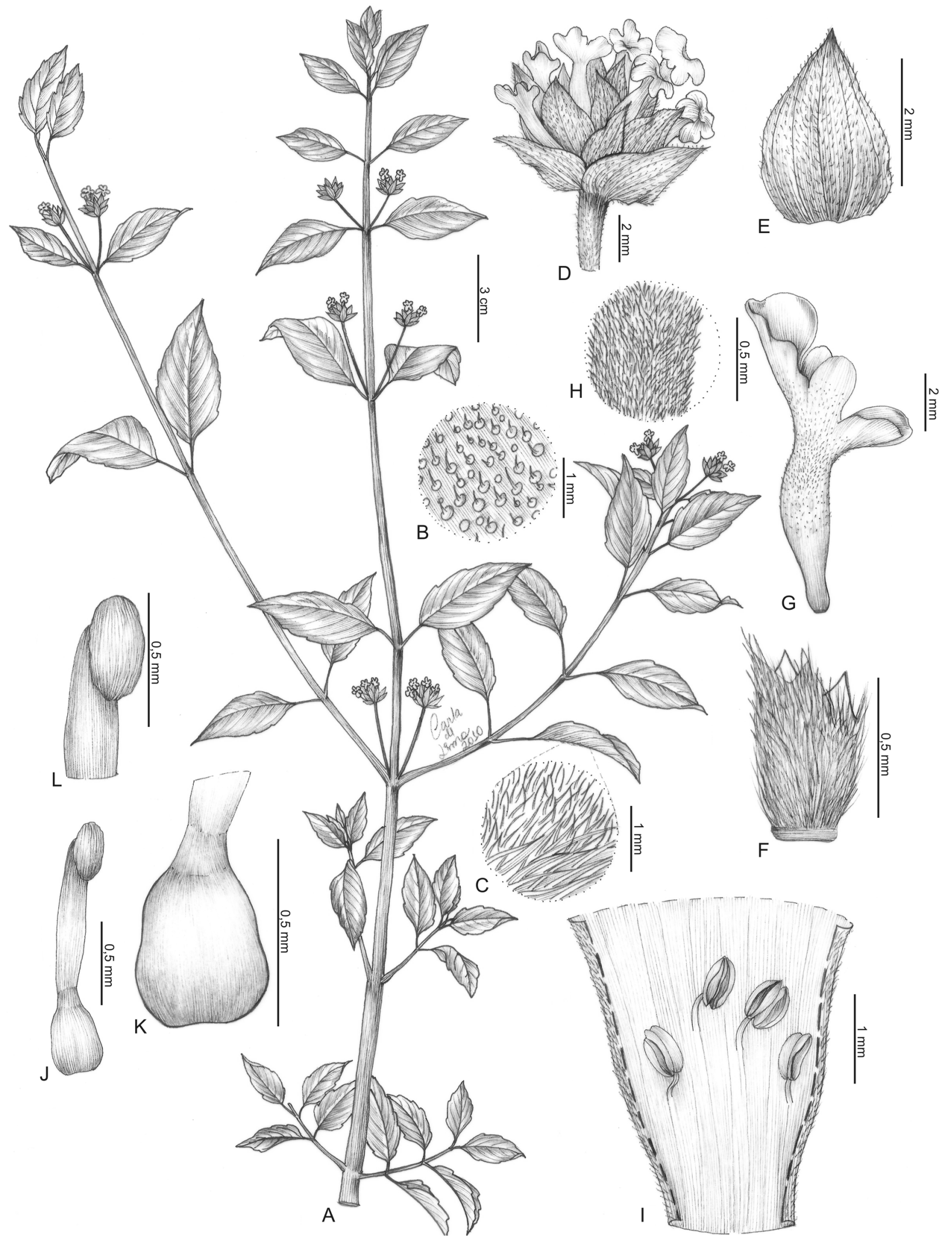

Figura 7. Lantana fucata: A- hábito; B- detalhe da lâmina, face adaxial; C- detalhe da lâmina, face abaxial; D- inflorescência; E- brácteas; F- cálice; Gcorola; H- detalhe do indumento da corola; I- detalhe do androceu; J- gineceu; K- ovário; L- estigma (França 894). 


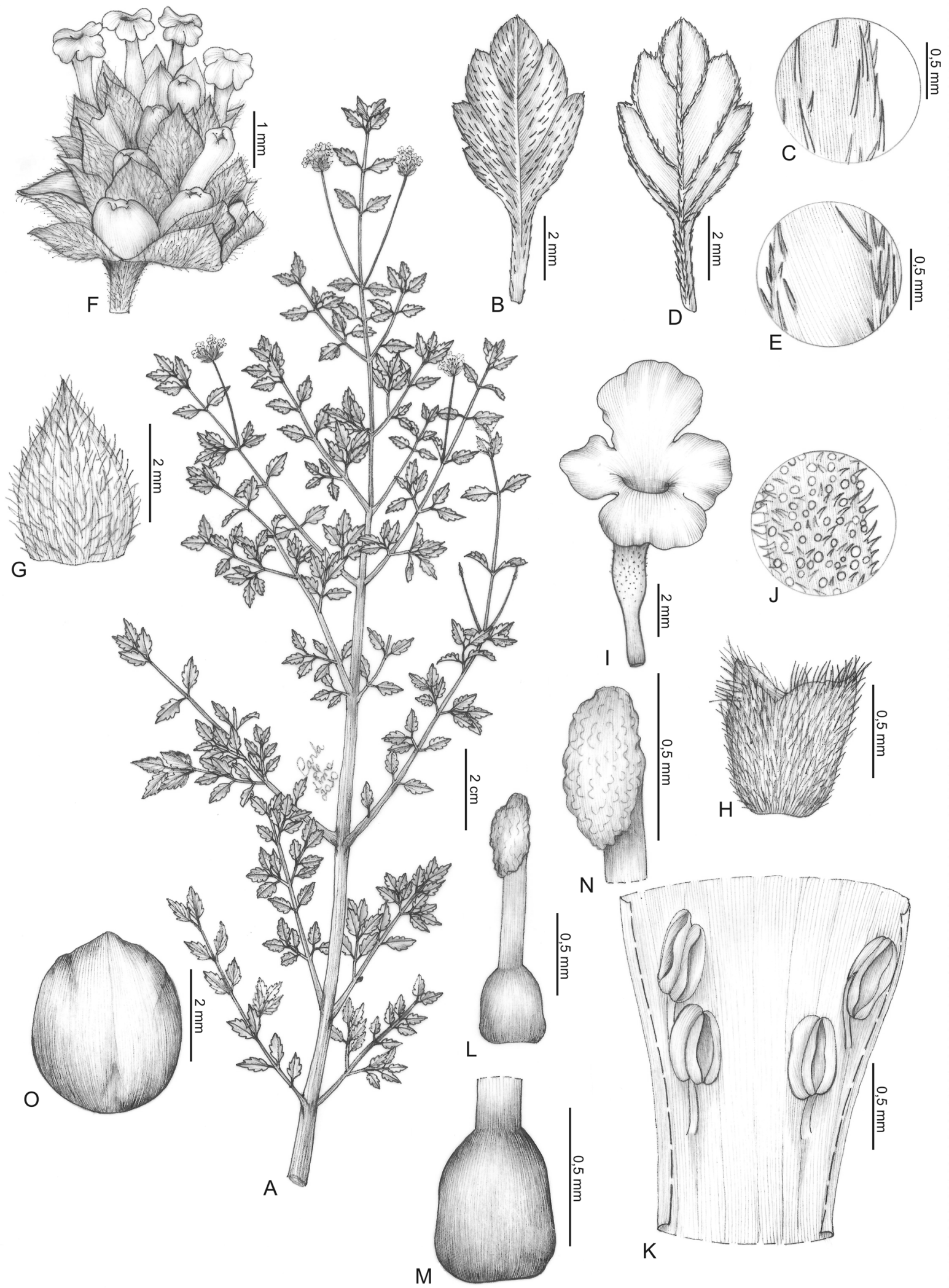

Figura 8. Lantana gracilis: A- hábito; B- folhas, face adaxial; C- detalhe da lâmina, face adaxial; D- folha , face abaxial; E- detalhe da lâmina, face abaxial; F- inflorescência; G- brácteas; H- cálice; I- corola; J- detalhe do indumento da corola; K- detalhe do androceu; L- gineceu; M- ovário; Nestigma; O- fruto (Melo 974 e T. Silva 19). 


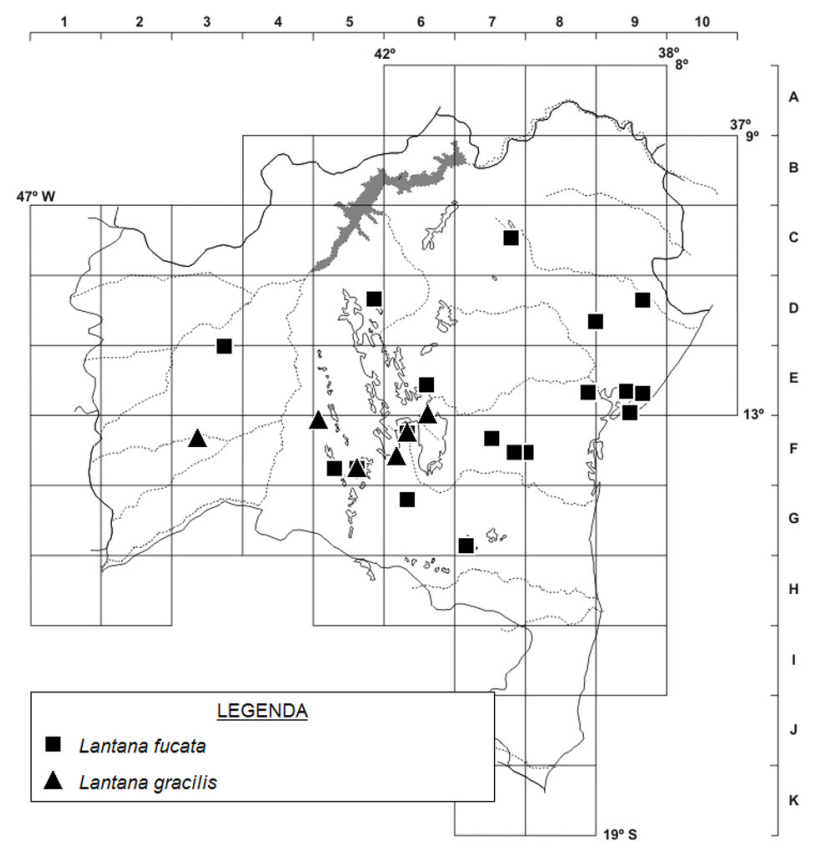

Figura 9. Mapa de distribuição de Lantana fucata e L. gracilis no estado da Bahia.

$5 \times 1,5-2 \mathrm{~mm}$, ápice agudo, persistentes no fruto. Flores com cálice ca. $2 \mathrm{~mm}$ compr., seríceo, acrescente no fruto, truncado a levemente 4-lobulado, lobos obtusos; corola com tubo lilás, ca. $7 \mathrm{~mm}$ compr., fauce branca ou amarela, pubescente; filetes ca. 0,4 mm compr. Frutos globosos a subglobosos, vináceos, glabros, mesocarpo tênue, ca. 3,5 × 3,2 $\mathrm{mm}$.

Espécie encontrada na América tropical. E/F6, F3, F5, F6: Campo Rupestre e Cerrado. Floresce e frutifica nos meses de janeiro a abril, junho e novembro.

Material selecionado - Abaíra, abr. 1994, E. Melo et al. 974 (HUEFS); Aracatu, entre Vitória da Conquista e Brumado, jan. 1974, R.M. Harley et al. 15027 (holótipo TEX, isótipos CEPEC, K); Caetité, nov. 1992, M.M. Arbo et al. 5641 (SPF); Correntina, jun. 1992, M.A. Silva et al. 1307 (IBGE, US); Mucugê, fev. 1997,

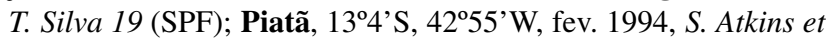
al. CFCR 14465 (ESA, SPF); Rio de Contas, 1335'15"S, 4148'11"W, mar. 1977, R.M. Harley et al. 20053 (CEPEC).

Lantana gracilis caracteriza-se por apresentar hábito subarbustivo com sistema subterrâneo desenvolvido, folhas com lâmina elíptica, 6-9 mm compr., e inflorescências maiores que as folhas.

\section{Lantana hypoleuca Briq., Bull. Herb. Boissier, série 2,} 4: 1064.1904.

Figuras 10 e 12.

Arbusto 0,5-2 $\mathrm{m}$ alt.; ramos decumbentes (escandentes), sem acúleos, tomentosos. Folhas decussadas ou 3verticiladas, cartáceas; pecíolo 8-10 mm compr.; lâmina 4,5$6 \times 1,5-2 \mathrm{~cm}$, elíptica, canescente, ápice agudo a atenuado, crenada, base aguda, não revoluta, face adaxial glabescente, abaxial tomentosa. Inflorescências (1)2 por axila, 1-4 cm compr.; pedúnculo 1-8,5 cm compr., seríceo; raque 4-6 cm compr., alongada na frutificação (4,5-6,5 cm compr.); brácteas verdes, tomentosas, diferenciadas em 2 externas ovais, 5-7 $\times$ ca. $4 \mathrm{~mm}$, ápice agudo a atenuado, internas ovais ca. $5 \times 1,5 \mathrm{~mm}$, ápice atenuado, persistentes no fruto. Flores com cálice ca. $1 \mathrm{~mm}$ compr., velutino, acrescente no fruto, truncado a 4-lobulado, lobos obtusos; corola [cor não vista], tubo 3-4,5 mm compr., tomentosa [filetes não visto]. Frutos ovoides, vináceos, glabros, mesocarpo suculento, $2,5-3,5 \times 2-3 \mathrm{~mm}$.

Brasil e Paraguai. No Brasil, ocorre nos estados da Bahia, Goiás, Distrito Federal, Minas Gerais, Rio de Janeiro e São Paulo. F6: Campo Rupestre. Encontrada com flores e frutos em janeiro.

Material examinado - Rio de Contas, jan. 1999, T.B. Cavalcanti 2448 (HUEFS).

Lantana hypoleuca caracteriza-se por apresentar folhas com superfície abaxial tomentosa, inflorescências até $4 \mathrm{~cm}$ compr., menores que as folhas, flores com corola subcarnosa, lilás em outras localidades, ca. $5 \mathrm{~mm}$ compr. Assemelha-se a L. trifolia, com quem compartilha a forma das brácteas, as quais possuem tamanho igual ou menor que a corola, porém diferencia-se dela pelas inflorescências menores que as folhas.

8. Lantana lucida Schauer in A.DC., Prodr. 11: 602. 1847. Figuras 11 e 12.

Arbusto 1,5-2 m alt.; ramos eretos e ou decumbentes, sem acúleos, estrigosos. Folhas decussadas, cartáceas a coriáceas, pecíolo 4-6 mm compr.; lâmina 3,5-10,5 × 1,5$2,5 \mathrm{~cm}$, elíptica, nitente; ápice agudo, margem serreada, base decorrente, revoluta, glabrescente em ambas as faces. Inflorescência 1 por axila, 4,5-6 cm compr., igual ou maior que as folhas; pedúnculo $3,5-5 \mathrm{~cm}$ compr., estrigoso a glabrescente ou glandular; raque ca. $1 \mathrm{~cm}$ compr., alongada na frutificação (ca. $2 \mathrm{~cm}$ compr.); brácteas verdes, seríceas, diferenciadas em 2 externas largo-ovais, 6,5-10 × 5-6 mm, ápice agudo a atenuado, as internas ovais ca. 5-6 × 2,5-3 $\mathrm{mm}$, ápice atenuado, persistentes no fruto. Flores com cálice 1-2 mm compr., ciliado, acrescente no fruto, 5-lobulado, lobos obtuso; corola com tubo branco, 8-10 mm compr., fauce branca ou amarela, pubescente; filetes ca. $0,5 \mathrm{~mm}$ compr. Frutos largo-ovoides, vináceos, glabros, mesocarpo suculento, ca. $4 \times 3,5 \mathrm{~mm}$.

No Brasil, encontrada nos estados de Alagoas, Sergipe e Bahia D/E9, D9/10, E9, F8. Restingas. Floresce e frutifica nos meses de maio, agosto e setembro.

Material selecionado - Cairu, set. 1993, M.L. Guedes et al. s.n. (ALCB 26610); Entre Rios, maio 1981, S.A. Mori \& B.M. Boom 14183 (NY); Esplanada, ago. 1996, L.P. Queiroz et al. 4673 (HUEFS, SPF); Lauro de Freitas, maio 1989, R. Soeiro 90 (HRB); Salvador, set. 1983, A.M. Carvalho \& M.L. Guedes 1911 (CEPEC); Valença, ago. 1980, L.A. Mattos-Silva et al. 1026 (CEPEC, HUEFS, MBM). 


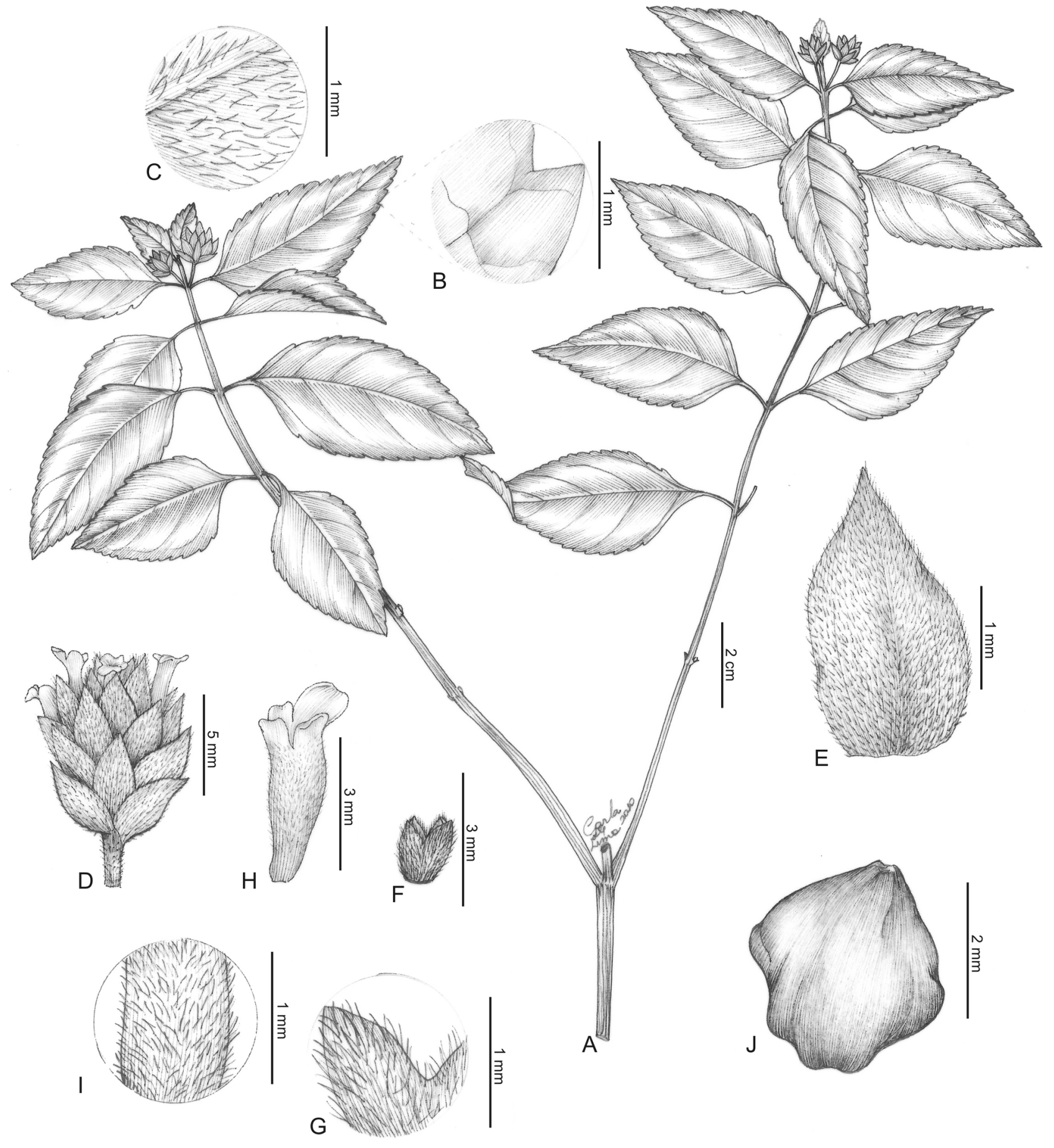

Figura 10. Lantana hypoleuca: A- hábito; B- detalhe da lâmina, face adaxial; C- detalhe da lâmina, face abaxial; D- inflorescência; E- brácteas; Fcálice; G- detalhe do indumento do cálice; H- corola; I- detalhe do indumento da corola; J- fruto (Cavalcanti 2448). 


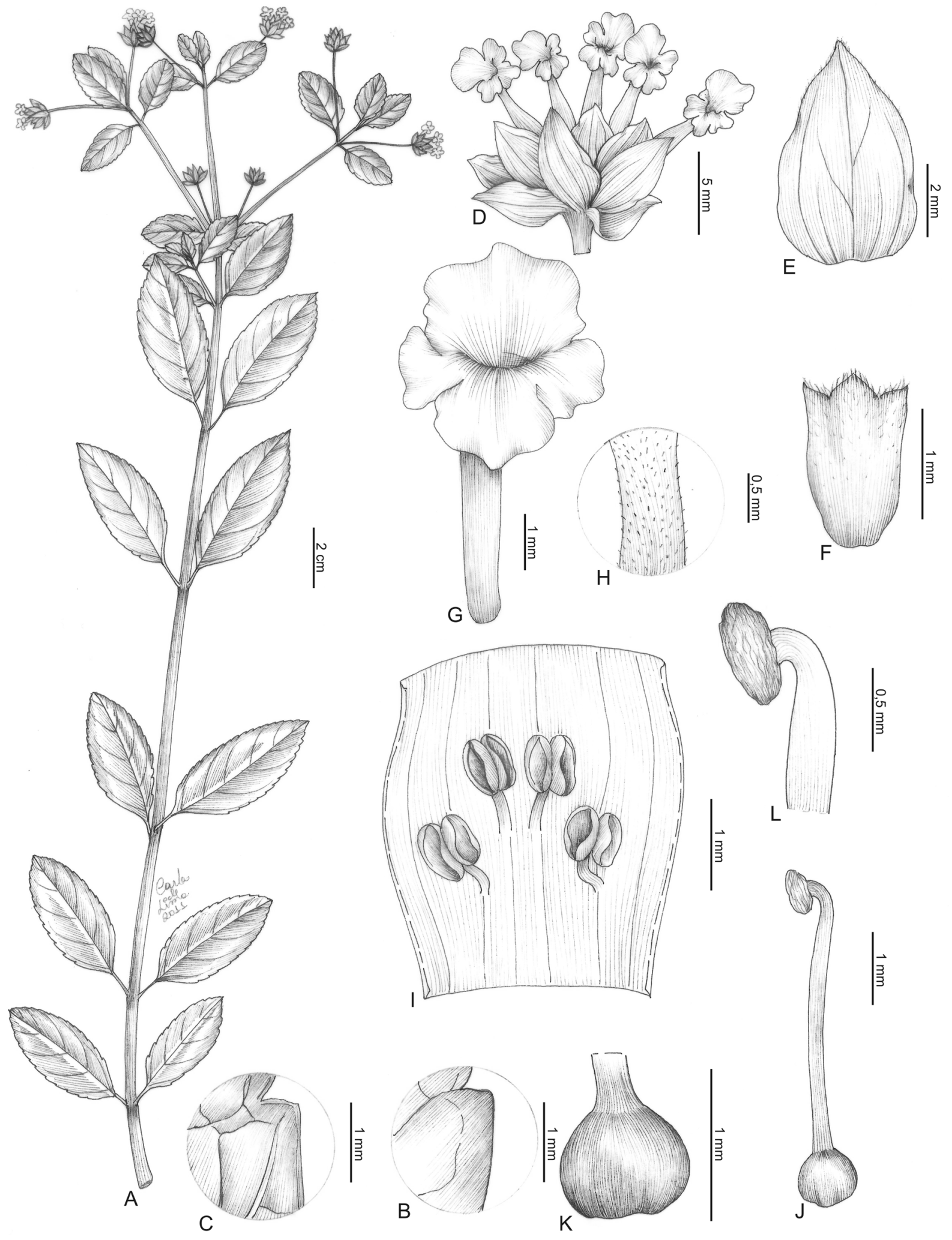

Figura 11. Lantana lucida: A- hábito; B- detalhe da lâmina, face adaxial; C- detalhe da lâmina, face abaxial; D- inflorescência; E- brácteas; F- cálice; G- corola; H- detalhe do indumento da corola; I- detalhe do androceu; J- gineceu; K- ovário; L- estigma (Queiroz 4673). 


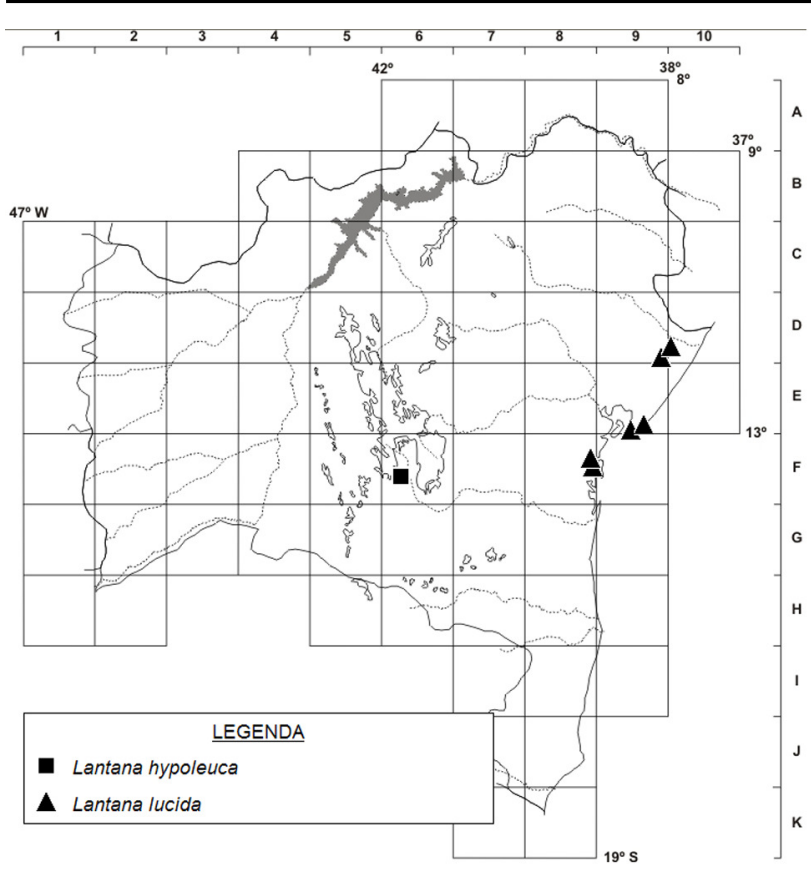

Figura 12. Mapa de distribuição de Lantana hypoleuca e L. lucida no estado da Bahia.

Lantana lucida caracteriza-se por apresentar folhas cartáceas a coriáceas, inflorescências menores ou do tamanho das folhas, flores branca e grandes, ca. $1 \mathrm{~cm}$ compr. Assemelha-se a L. salzmannii Schauer, com quem é simpátrica, por apresentar folhas coriáceas, mas difere por possuir flores maiores, com corola branca, além de suas folhas serem nitentes.

9. Lantana pohliana Schauer in A.DC, Prodr. 11: 601. 1847. Figuras 13 e 15 .

Arbusto 1-3 m alt.; ramos eretos, sem acúleos; ramos, folhas e inflorescências viscosos, hirsutos com tricomas filamentosos e glandulares. Folhas decussadas, cartáceas; pecíolo 9-12 mm compr.; lâmina 1,5-7,5 × 1-4 cm, oval a elíptica, fosca, ápice agudo a atenuado, margem serreada, base subcordada a cordada, não revoluta. Inflorescência 1 por axila, 3-8 cm compr., maior que as folhas; pedúnculo $1,5-4,5 \mathrm{~cm}$ compr.; raque ca. $5 \mathrm{~mm}$ compr., alongada na frutificação (ca. $1 \mathrm{~cm}$ compr.); brácteas verdes, hirsutas, não diferenciadas, lanceoladas a oblongas, $5-8 \times 1-1,5 \mathrm{~mm}$, ápice aristado, não persistentes no fruto. Flores com cálice 1,5-2 mm compr., ciliado, acrescente no fruto levemente truncado a 5-lobado, lobos arredondados; corola com tubo lilás, $1-1,2 \mathrm{~cm}$ compr., fauce branca, puberulenta; filetes $0,4-$ $0,5 \mathrm{~mm}$ compr. Frutos ovoides, vináceos, glabros, mesocarpo suculento, 5-6 × 4-4,5 mm.

No Brasil, encontrada nos estados de Pernambuco, Tocantins, Bahia e Minas Gerais. D4, D5, E4, F3, F4: Caatinga, Cerrado, Mata de Cipó e Mata Ciliar. Floresce e frutifica nos meses de abril a julho e outubro.
Material selecionado - Barra, jul. 1974, A.L. Costa s.n. (ALCB 3586); Bom Jesus da Lapa, $13^{\circ} 15^{\prime} \mathrm{S}, 4^{\circ} 26^{\prime} \mathrm{W}$, abr. 1980, R.M. Harley et al. 21362 (CEPEC, NY); Correntina, 1320'S, $44^{\circ} 38^{\prime}$ 'W, abr. 1980, R.M. Harley et al. 21658 (CEPEC, NY); Divinópolis, maio 1968, R.P. Belém 3644 (CEPEC, NY); Ibotirama, jun. 1986, G.C.P. Pinto 63/86 (ALCB, CEPEC, HRB, HUEFS, IPA); Morpará, $11^{\circ} 44^{\prime}$ 'S, $42^{\circ} 59^{\prime} \mathrm{W}$, O.A. Salgado \& H.P. Bautista 312 (HRB, RB); ib., $13^{\circ} 23^{\prime} \mathrm{S} 43^{\circ} 13^{\prime} \mathrm{W}$, abr. 1980, R.M. Harley et al. 21404 (CEPEC, IPA, NY); ib., fazenda Imbuzeiro, $13^{\circ} 09^{\prime} \mathrm{S}, 43^{\circ} 22^{\prime} \mathrm{W}$, abr. 1980, R.M. Harley et al. 21536 (CEPEC, IPA, NY, RB).

Lantana pohliana caracteriza-se por apresentar ramos longos, delgados e viscosos devido à presença de tricomas glandulares, folhas decíduas na estação seca, pedúnculos patentes e maiores que as folhas, também com tricomas glandulares. Assemelha-se a L. viscosa por apresentar inflorescências maiores que as folhas, patentes, brácteas iguais e ovais e cálice tubular, porém diferencia-se pelos ramos sem acúleos e pelos tricomas glandulares nos pedúnculos.

10. Lantana radula Sw., Prodr.: 92. 1788.

Figuras 14 e 15.

Arbusto 1-2 m alt.; ramos patentes, decumbentes, sem acúleos; ramos, pecíolos e inflorescências hirsutos, tricomas filamentosos e brancos. Folhas decussadas, cartáceas; pecíolo 2-10 mm compr.; lâmina 2,2-6 × 1,5-3,5 cm, elíptica, fosca, escabra, ápice agudo a atenuado, margem serreada, base decorrente, revoluta, glabrescente em ambas as faces. Inflorescência 1 ou 2 por axila, 3-7 cm compr., do mesmo tamanho ou maior que as folhas; pedúnculo $2-6 \mathrm{~cm}$ compr., hirsuta a glabrescente; raque $0,7-1,2 \mathrm{~cm}$ compr., alongada na frutificação (1,5-3,5 cm compr.); brácteas verdes, hirtelas, diferenciadas em 2 externas largo-ovais, 7-8 $\times$ 4-6 mm, ápice agudo a atenuado, as internas ovais, ca. 6-7 $\times 2-3 \mathrm{~mm}$, ápice agudo, persistentes no fruto. Flores com cálice ca. $1,5 \mathrm{~mm}$ compr., tomentoso, acrescente no fruto, 4lobado, lobos obtusos; corola branca, tubo ca. 5-10 mm compr., puberulenta; filetes 0,3-05 mm compr. Frutos ovoides, vináceos, glabros, mesocarpo tênue, 2,5-3 × 2-2,5 $\mathrm{mm}$.

Neotropical. No Brasil, ocorre nos estados de Rio Grande do Norte, Ceará, Alagoas, Pernambuco, Paraíba, Bahia, Minas Gerais e Goiás. D9, D9/10, E6, E8, E8/9, E9, F6, F8, G7, G8: caatinga, campo rupestre, restinga litorânea, e mata de altitude. Floresce e frutifica em fevereiro e março, maio, junho e novembro.

Material selecionado - Água Fria, maio. 1984, J.E.M. Brazão \& C.G. Oliveira 320 (PEUFR); Almadina, $14^{\circ} 44^{\prime}$ S, $39^{\circ} 41^{\prime} \mathrm{W}$, fev.1997, J.G. Jardim et al. 1012 (NY); Barra da Estiva, mar. 1980, R.M. Harley et al. 20907 (CEPEC); Barra do Choça, jun.1987, M.L. Guedes 1274 (ALCB); Camaçari, nov. 1982, L.R. Noblick et al. 2130 (HUEFS); Castro Alves, 1351'S, 39²8' W, jun.1993, L.P. Queiroz \& T.S.N. Sena 3233 (HUEFS); Esplanada, fev. 1985, A.J.E. Carvalho 11 (PEUFR); Lamarão de Passé, jun. 1994, M.L. Guedes \& F. Nawaro 3274 (HUEFS); Maraú, fev. 1983, 


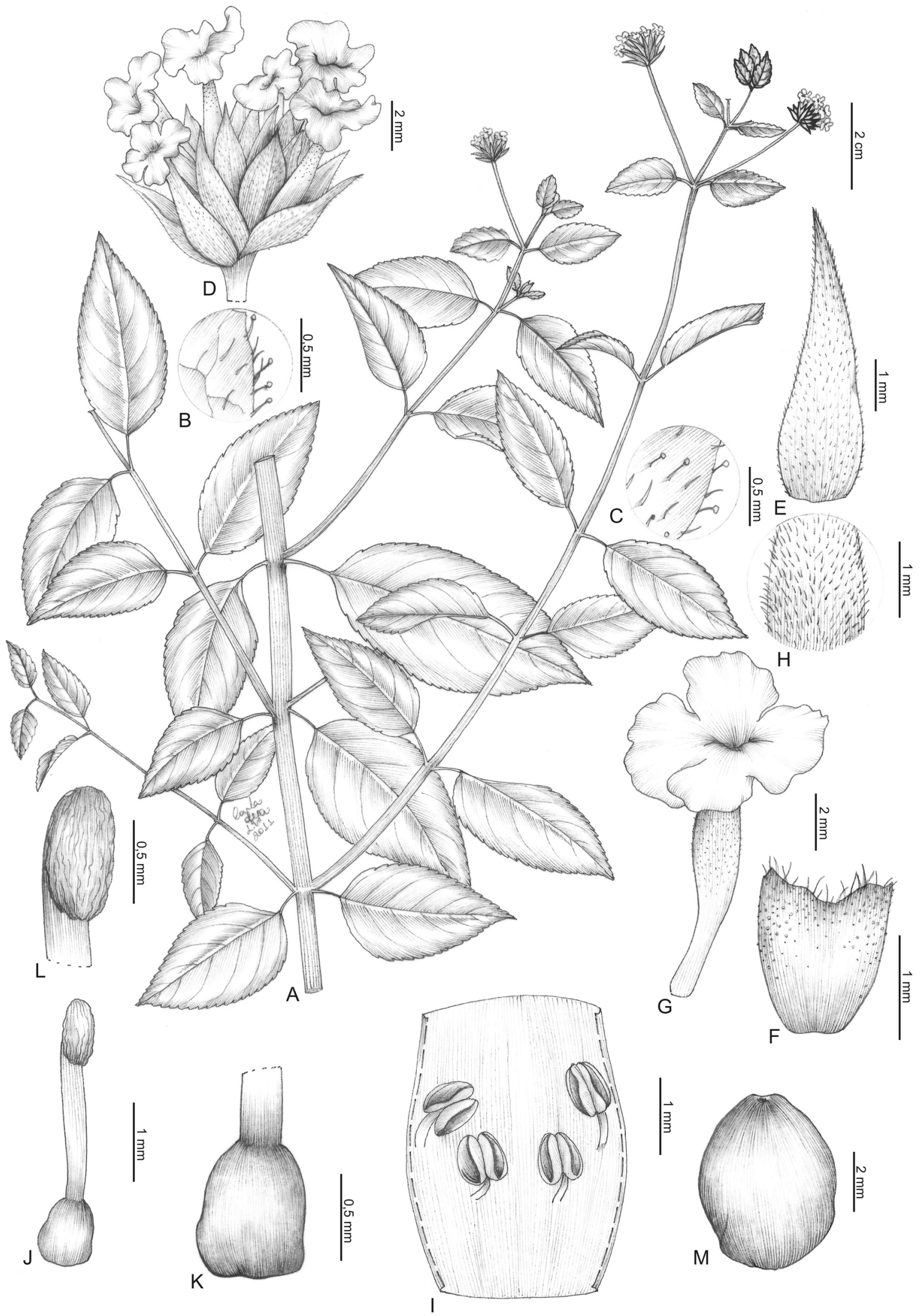

Figura 13. Lantana pohliana: A- hábito; B- detalhe da lâmina, face adaxial; C- detalhe da lâmina, face abaxial; D- inflorescência; E- brácteas; F- cálice; G- corola; H- detalhe do indumento da corola; I- detalhe do androceu; J- gineceu; K- ovário; L- estigma (Harley 21362). 


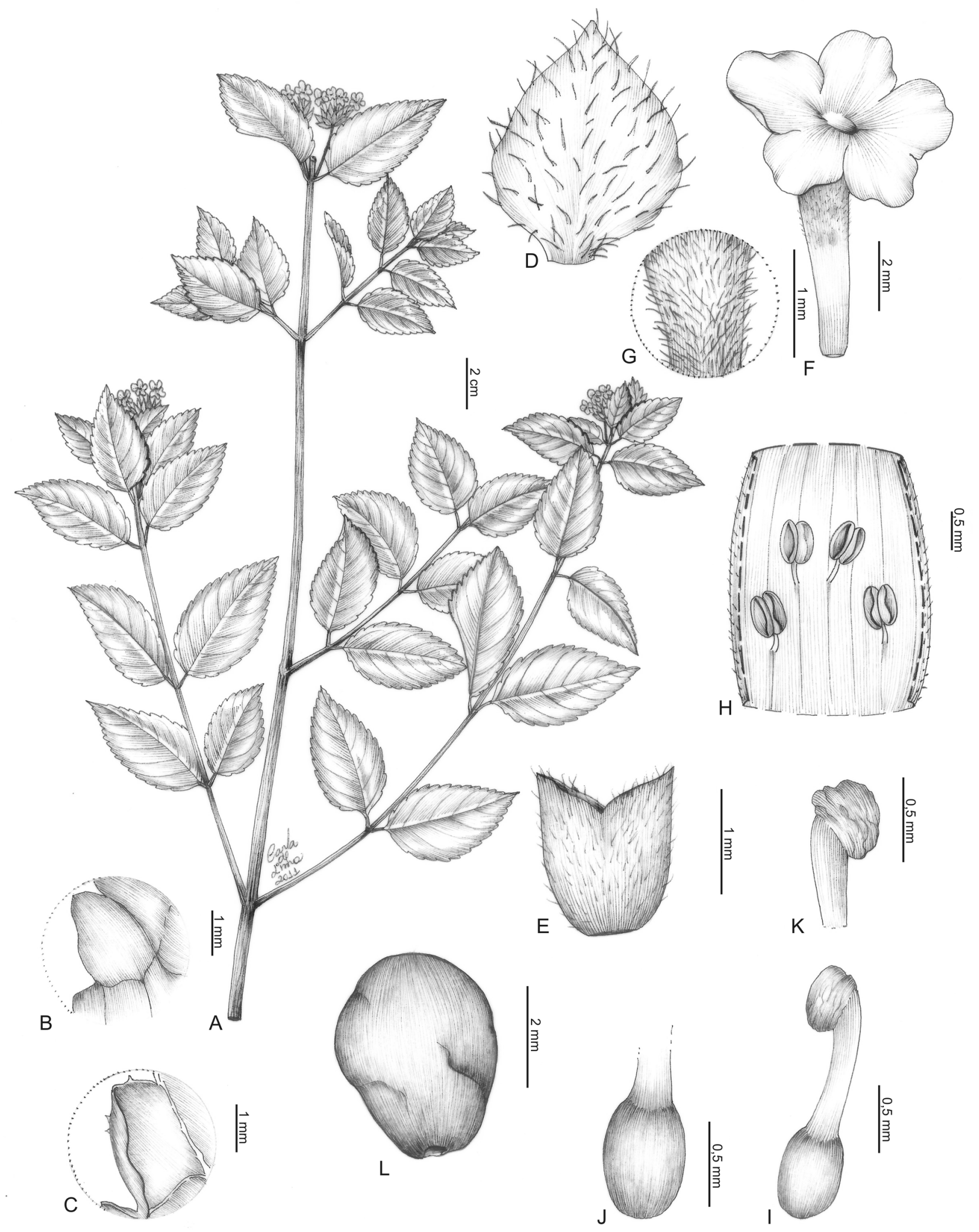

Figura 14. Lantana radula: A- hábito; B- detalhe da lâmina, face adaxial; C- detalhe da lâmina, face abaxial; D- brácteas; E- cálice; F- corola; Gdetalhe do indumento da corola; H- detalhe do androceu; I- gineceu; J- ovário; K- estigma; L- fruto (Noblick 2130 e França 1104). 


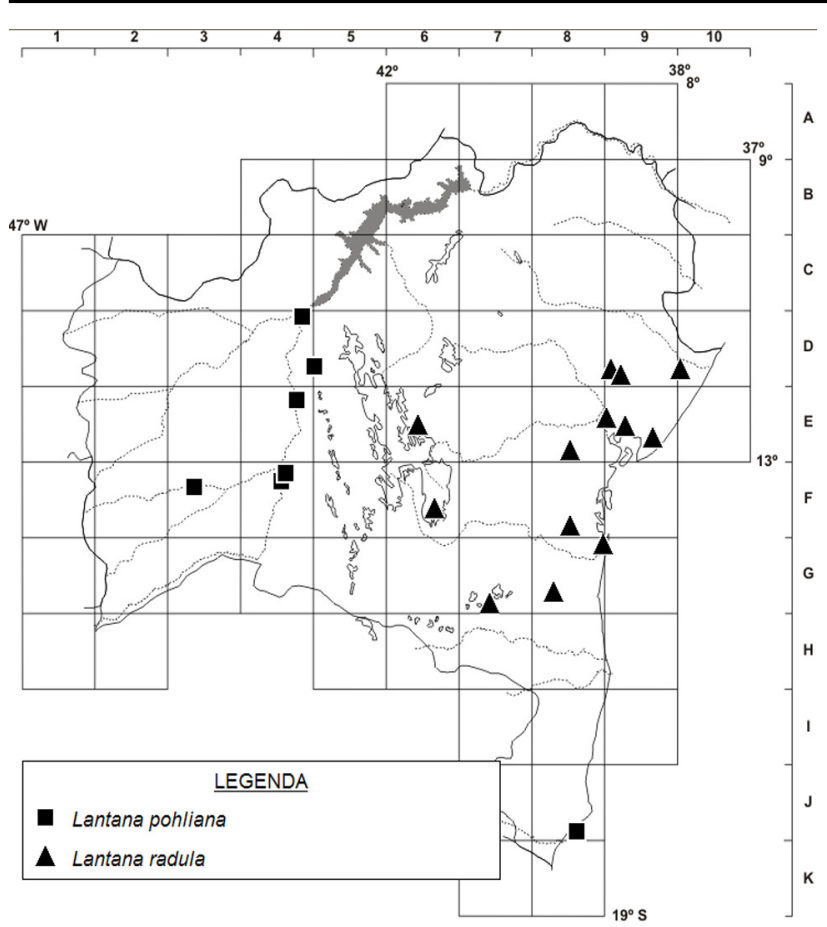

Figura 15. Mapa de distribuição de Lantana pohliana e L. radula no estado da Bahia.

A.M. Carvalho \& T. Plowman 1452 (CEPEC); Palmeira, jun. 1952, G. Pinto s.n. (ALCB 6982); Salvador, fev. 1992, G.C.P. Pinto et al. 5/92 (HRB). Santa Terezinha, $12^{\circ} 51^{\prime}$ 'S, $39^{\circ} 28^{\prime} \mathrm{W}$, mar. 1995, F. França et al. 1096, 1104 (HUEFS). Santo Amaro, nov. 1983, G.C.P. Pinto et al. 370/83 (ALCB, CEPEC, HUEFS, IPA, MBM). São Gonçalo, mar. 1981, M.L. Guedes \& L.P. Queroz 181 (ALCB).

Lantana radula caracteriza-se por apresentar indumento hirsuto com tricomas filamentosos e brancos em toda planta, folhas revolutas, brácteas externas obovais com ápice obtuso e brácteas internas ovais, com ápice acuminado, e corola branca. Se assemelha a L. undulata, com quem compartilha a forma das folhas e cor da corola, porém diferencia-se por apresentar indumento hirsuto e brácteas externas obovais.

11. Lantana salzmannii Schauer in A.DC., Prodr. 11: 602. 1847.

= Lantana salzmannii f. albiflora Moldenke, Phytologia 41(8): 449. 1979.

Figuras 16 e 18.

Subarbusto 0,5-1,8 m alt.; ramos eretos, sem acúleos, estrigosos. Folhas decussadas, cartáceas a coriáceas; pecíolo 2-7 mm compr.; lâmina 1,5-4 × 1-2 cm, elíptica a oval, fosca, ápice obtuso a arredondado, margem crenada, base decorrente, revoluta, face adaxial estrigosa a glabrescente, a abaxial hirsuta, com tricomas esparsos ao longo das nervuras. Inflorescência 1 por axila, 2-6 cm compr., menor, do mesmo tamanho ou maior que as folhas; pedúnculo 1,5-5 cm compr., estrigoso; raque 0,7-1,2 cm compr., alongada na frutificação (1,5-3,5 cm compr.); brácteas verdes, hirtelas, diferenciadas em 2 externas elípticas, 6-9 ×3-6 mm, ápice obtuso a arredondado, as internas elípticas, ca. 4,5-6 ×2-3 $\mathrm{mm}$, ápice obtuso, persistentes nos frutos. Flores com cálice 1-1,5 mm compr., ciliado, hirtelo, não acrescente no fruto, levemente truncado a 2-lobado, lobos obtuso; corola lilás ou branca, tubo 5-7 mm compr., puberulenta; filetes ca. 0,3-0,5 mm compr.; gineceu 2-3 mm compr. Frutos ovoides, vináceos, glabros, mesocarpo tênue, ca. $3 \times 2,3 \mathrm{~mm}$.

No Brasil, é encontrada nos estados de Sergipe e Bahia. D10, E9, G8, H8/9, I8/9, J8: dunas, mata hidrófila e restingas. Floresce e frutifica nos meses de janeiro, fevereiro, maio e agosto.

Material selecionado - Camaçari, ago. 1995, G. Hatschbach et al. 62871 (MBM); Cumuruxatiba, $17^{\circ} 13^{\prime}$ 'S, 39 $9^{\circ} 15^{\prime} \mathrm{W}$, jan. 1977, R.M. Harley et al. H 18072 (CEPEC, K); Jandaíra, ago.1995, G. Hatschbach et al. 63168 (MBM); Maraú, maio 1980, R.M. Harley et al. 22111 (CEPEC). Salvador, fev .1997, T. Silva 20 (SPF); Santa Cruz Cabrália, s.d., S. Mori et al. 10360 (isótipos de $L$. salzmanii f. albiflora CEPEC, NY); Valença, ago. 1980, A.M. Carvalho et al. 321 (CEPEC). J. Blanchet 1005 (BM); Comandatuba, $15^{\circ} 20^{\prime} \mathrm{S}, 39^{\circ} 00^{\prime} \mathrm{W}$, jan. 1977, R.M. Harley et al. 18239 (CEPEC); 1830, M. Salzmann 425 (lectótipo de L. salzmanii G-DC).

Lantana salzmannii caracteriza-se por apresentar folhas com lâminas elípticas, coriáceas, pedúnculos maiores que as folhas, brácteas externas com ápice obtuso a arredondado.

12. Lantana tiliifolia Cham., Linnaea 7(1): 122.1832.

$=$ Lantana tiliifolia var. glandulosa Schauer in Martius,

Fl. Bras. 9: 258. 1851.

Figuras 17 e 18 .

Arbusto 0,5-2 m alt., sem acúleos; ramos, folhas e inflorescências glandulosas. Folhas decussadas, cartáceas; pecíolo 0,4-2 mm compr.; lâmina 4-8 ×3,5-5,5 cm, elíptica a oval, fosca, ápice atenuado, margem serreada, base cordada, não revoluta. Inflorescência 1 por axila, 5,5-12 cm compr., igual ou do tamanho das folhas; pedúnculo 4-11 cm compr., estrigoso; raque $0,5-1 \mathrm{~cm}$ compr., não alongada na frutificação; brácteas verdes, diferenciadas em 2 externas lanceoladas, ca. $6 \times 2 \mathrm{~mm}$, ápice obtuso, as internas estreitoelípticas, ca. $4 \times 2 \mathrm{~mm}$, ápice obtuso, persistentes no fruto. Flores com cálice 1-2 mm compr., viloso, não acrescente no fruto, 2-lobado, lobos obtusos; corola branca, puberulenta, tubo 8-10 mm compr.; filetes 0,3-0,4 mm compr. Frutos ovoides, vináceos, glabros, mesocarpo suculento, ca. $2,5 \times$ $2 \mathrm{~mm}$.

Neotropical. No Brasil, ocorre nos estados de Pernambuco, Alagoas, Bahia, Espírito Santo, Minas Gerais e Rio de Janeiro. D6, E6, E9, E/F9, F6, G5, G8/9, H8/9, I8, J8: em beira de mata, mata úmida, restinga, campo rupestre e também em áreas ruderais. Floresce e frutifica nos meses de março a julho, setembro e novembro.

Material selecionado - Alcobaça, set. 1978, S. Mori et al. 10635 (CEPEC, RB); Barra da Estiva, $13^{\circ} 26^{\prime} \mathrm{S}, 4^{\circ} 18^{\prime} \mathrm{W}$, mar. 


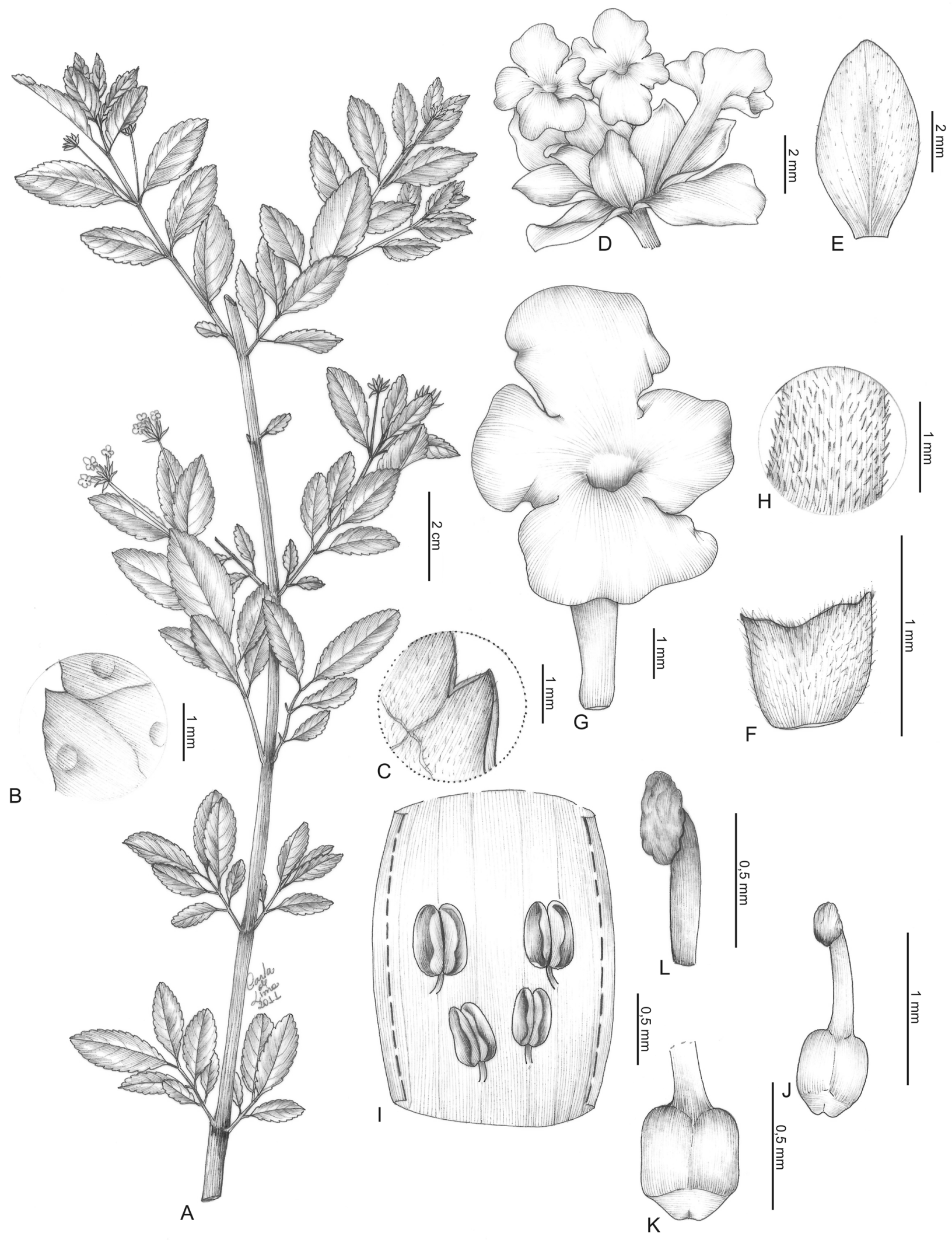

Figura 16. Lantana salzmannii: A- hábito; B- detalhe da lâmina, face adaxial; C- detalhe da lâmina, face abaxial; D- inflorescência; E- brácteas; Fcálice; G- corola; H- detalhe do indumento da corola; I- detalhe do androceu; J- gineceu; K- ovário; L- estigma (T. Silva 20 e Harley 22111 ). 


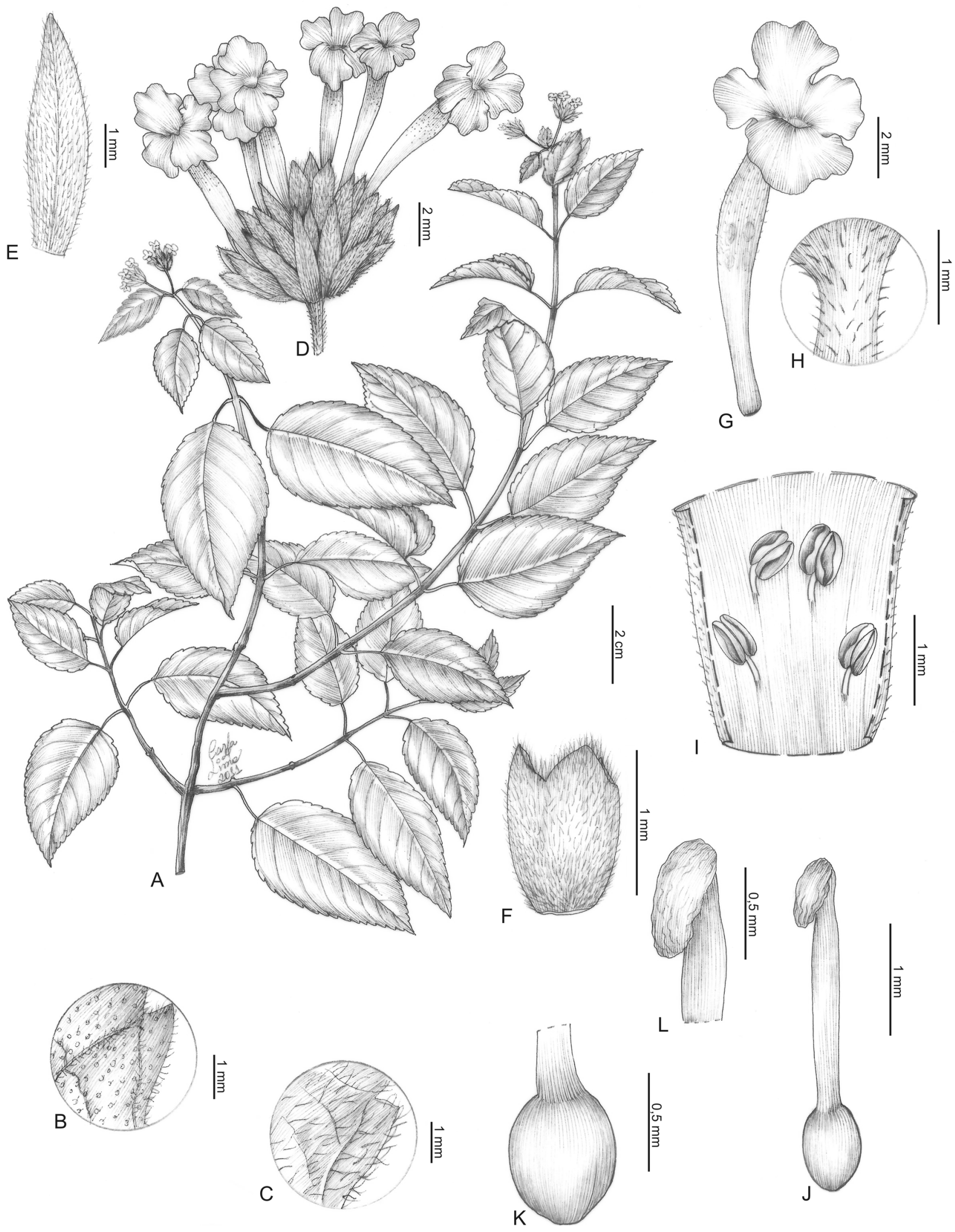

Figura 17. Lantana tiliifolia: A- hábito; B- detalhe da lâmina, face adaxial; C- detalhe da lâmina, face abaxial; D- inflorescência; E- brácteas; F- cálice; G- corola; H- detalhe do indumento da corola; I- detalhe do androceu; J- gineceu; K- ovário; L- estigma (Hage 1685). 


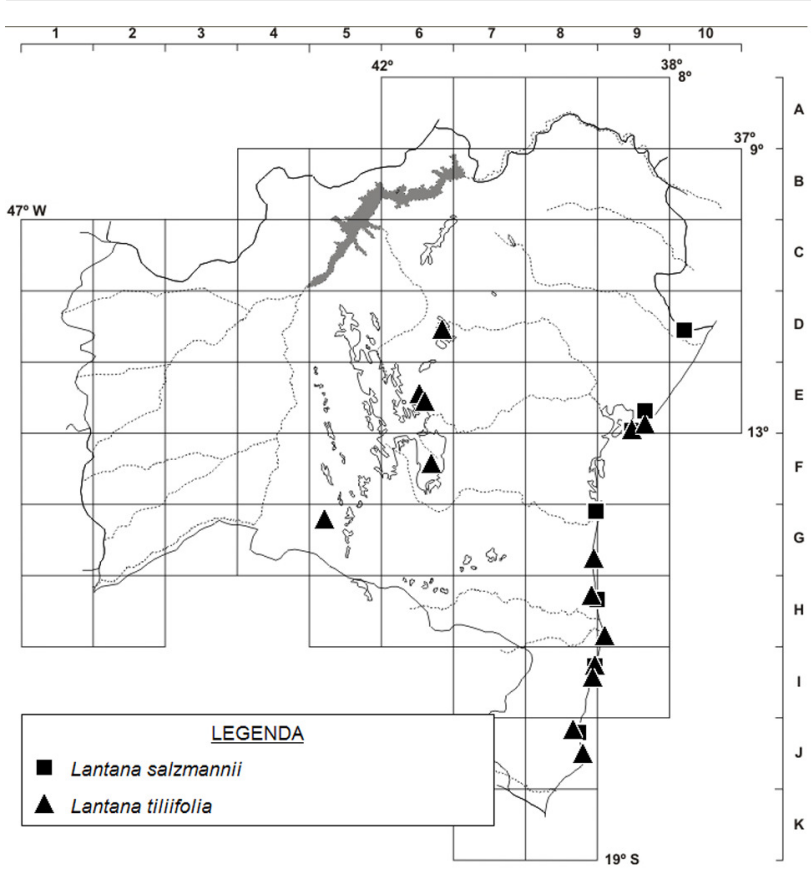

Figura 18. Mapa de distribuição de Lantana salzmannii e L. tiliifolia no estado da Bahia.

1980, R.M. Harley et al. 20935 (CEPEC, K); Belmonte, mar. 1988, F.S. Santos 841 (CEPEC); Guanambi, mar. 1981, S.B. Silva 240 (HRB, RB); Ilhéus, mar. 1995, J.A. Jesus \& L.A.M. Silva 2135 (CEPEC); Lauro de Freitas, jul.1988, R. Soeiro 13/88 (HRB); Morro do Chapéu, jun. 1980, R.M. Harley et al. 22935 (CEPEC); Palmeiras, $12^{\circ} 27^{\prime}$ 'S, 41 $28^{\prime}$ 'W, maio 1980, R.M. Harley et al. 22413 (CEPEC, K, SPF); Porto Seguro, jan. 1990, D.A. Folli 1054 (K); Prado, jun. 1984, J.E.M. Brazão \& C.G. Oliveira 360 (HRB); Salvador, jun. 1994, M.L. Alves s.n. (ALCB 25318); Santa Cruz Cabrália, nov. 1984, F. Souza \& M. Ferreira 458 (CEPEC); Una, maio 1983, J.L. Hage et al. 1685 (CEPEC, INPA); sem localidade: Siber s.n (lectótipo B-W 11502); 1840, J. Blanchet 3136 A (Lectótipo L. tiliaefolia var. glandulosa G-DC).

Lantana tiliifolia caracteriza-se por apresentar indumento glanduloso em toda a planta, folhas ovais com base cordada, pedúnculos maiores que as folhas, espigas com brácteas diferentes, as externas lanceoladas com ápice obtuso, brácteas internas estreito-elípticas com ápices agudos, persistentes na frutificação, e cálice tubular, não acrescente no fruto. Lantana tiliifolia compartilha a presença de indumento glandular com L. pohliana, mas diferencia-se pela forma e tamanho das folhas.

13. Lantana trifolia L., Sp. Pl. 2: 626. 1753.

Figuras 19 e 21.

Arbusto 1-2 m alt.; ramos inermes, eretos, decumbentes, sem acúleos, os jovens tomentosos, os adultos tomentosos, hirsutos ou estrigosos. Folhas decussadas a 3-verticiladas, cartáceas; pecíolo 3-20 mm compr.; lâmina 4-13 × 2-4,5 $\mathrm{cm}$, elíptica, fosca, ápice agudo a atenuado, margem serreada a crenada, base acuneada, não revoluta, face adaxial hirsuta a estrigosa, a abaxial tomentosa. Inflorescência 1-3 por axila, 4,5-11,5 cm compr., do tamanho ou maior que as folhas; pedúnculo 4-6,5 cm compr., estrigoso; raque ca. $7 \mathrm{~mm}$ compr., alongada na frutificação (1-3 cm de compr.); brácteas verdes, seríceas ou hirtelas, diferenciadas em 2 externas ovais lanceoladas, 6-10 × ca. $2 \mathrm{~mm}$, ápice caudado, as internas ovais, ca. 4-6,5 × ca. $2 \mathrm{~mm}$, ápice obtuso, persistentes no fruto. Flores com cálice 1,5-2,5 mm compr., velutino, não acrescente no fruto, levemente truncado a 2-lobado, lobos obtuso; corola com tubo lilás, raro branco, 4-7 mm compr., pubescente; filetes 0,3-0,5 mm compr. Frutos ovoides, vináceos, glabros, mesocarpo suculento, ca. $3 \times 3 \mathrm{~mm}$.

Neotropical, amplamente distribuída, encontrada em áreas ruderais, sendo considerada invasora. F6. Floresce e frutifica durante o todo o ano.

Material examinado - Rio de Contas, $13^{\circ} 11^{\prime} \mathrm{S}, 41^{\circ} 32^{\prime} \mathrm{W}$, T.R.S. Silva et al. 237 (HUEFS).

Lantana trifolia caracteriza-se por apresentar folhas coriáceas, verticiladas ou opostas, inflorescências com numerosas flores e brácteas externas ovais com ápice caudado. Assemelha-se a L. hypoleuca, como comentado naquela espécie.

14. Lantana undulata Schrank, Denkschr. Bot. Ges.

Regensb. 2: 117. 1822.

Figuras 20 e 21 .

Arbusto 0,15-2 m alt.; ramos inermes, eretos, decumbentes, sem acúleos, estrigosos. Folhas decussadas, membranáceas; pecíolo 4-5 mm compr.; lâmina 4-9 × 1$3,5 \mathrm{~cm}$, elíptica, fosca, ápice agudo a atenuado, margem serreada, base acuneada, não revoluta, face adaxial estrigosa a glabrescente, abaxial estrigosa ao longo da nervuras. Inflorescência 1 ou 2 por axila, 5-10,5 cm compr., igual ou do tamanho das folhas; pedúnculo 4,5-10 cm compr., estrigoso; raque ca. $5 \mathrm{~mm}$ compr., alongada na frutificação (2-3 cm compr.); brácteas verdes, hirtelas, diferenciadas em 2 externas oval-lanceoladas ca. $9 \times 7 \mathrm{~mm}$, ápice atenuado, as internas oval-lanceoladas, $7-9 \times$ ca. $3 \mathrm{~mm}$, ápice agudo a atenuado, persistentes no fruto. Flores com cálice 1-2 mm compr., truncado, seríceo, acrescente no fruto; corola com tubo branco, 6-10 mm compr., puberulento; filetes 0,3-0,5 mm compr. Frutos ovoides, vináceos, glabros, mesocarpo suculento, 2,5-3 × 2,3-3 mm.

No Brasil, ocorre de Pernambuco a Santa Catarina. E9, F8, G8, H8, H9, I8, J8, K8: restinga, duna e floresta ombrófila. Floresce e frutifica durante todo o ano.

Material selecionado - Alcobaça, set. 1978, S. Mori et al. 10634 (CEPEC, IPA, NY); Algodão, abr. 1991, R.P. Lyra-Lemos \& G.L. Esteves 1863 (MAC, SPF); Belmonte, mar. 1988, F.S. Santos 850 (CEPEC); Candeias, out. 1983, G.C.P. Pinto 274/83 (HRB); Caravelas, ago. 1961, A.P. Duarte 5920 (RB, SPF); Cravolândia, 3942'W, 13³0'S, nov. 1993, F. França et al. 891 (CEPEC, HUEFS); Guaratinga, fev. 1985, A. Gentry \& E. Zardini 49937 (CEPEC). Ilhéus, B. Luschnath s.n. (holótipo M); Itacaré, 14¹9'S, 


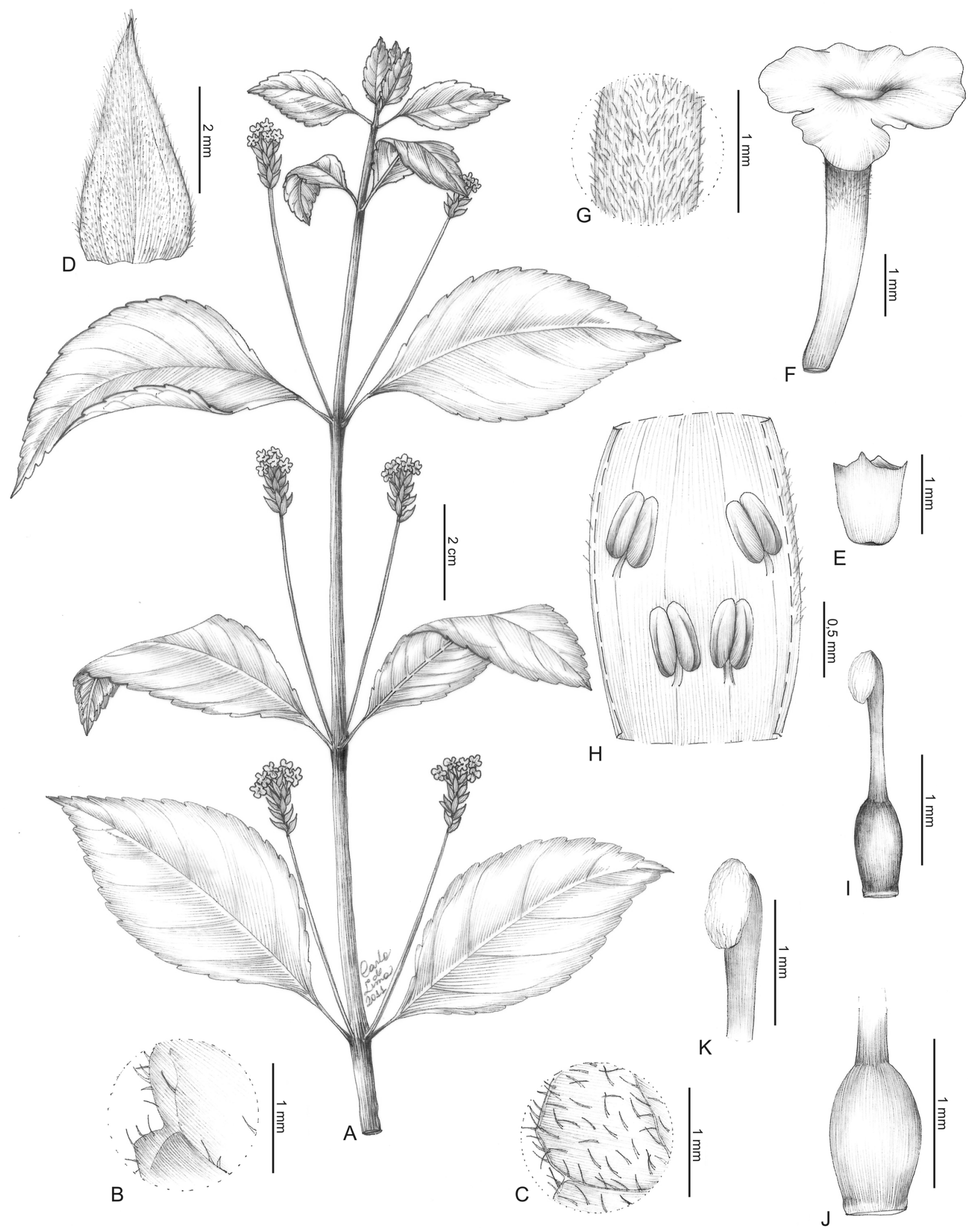

Figura 19. Lantana trifolia: A- hábito; B- detalhe da lâmina, face adaxial; C- detalhe da lâmina, face abaxial; D- brácteas; E- cálice; F- corola; Gdetalhe do indumento da corola; H- detalhe do androceu; I- gineceu; J- ovário; K- estigma (T. Silva 237). 


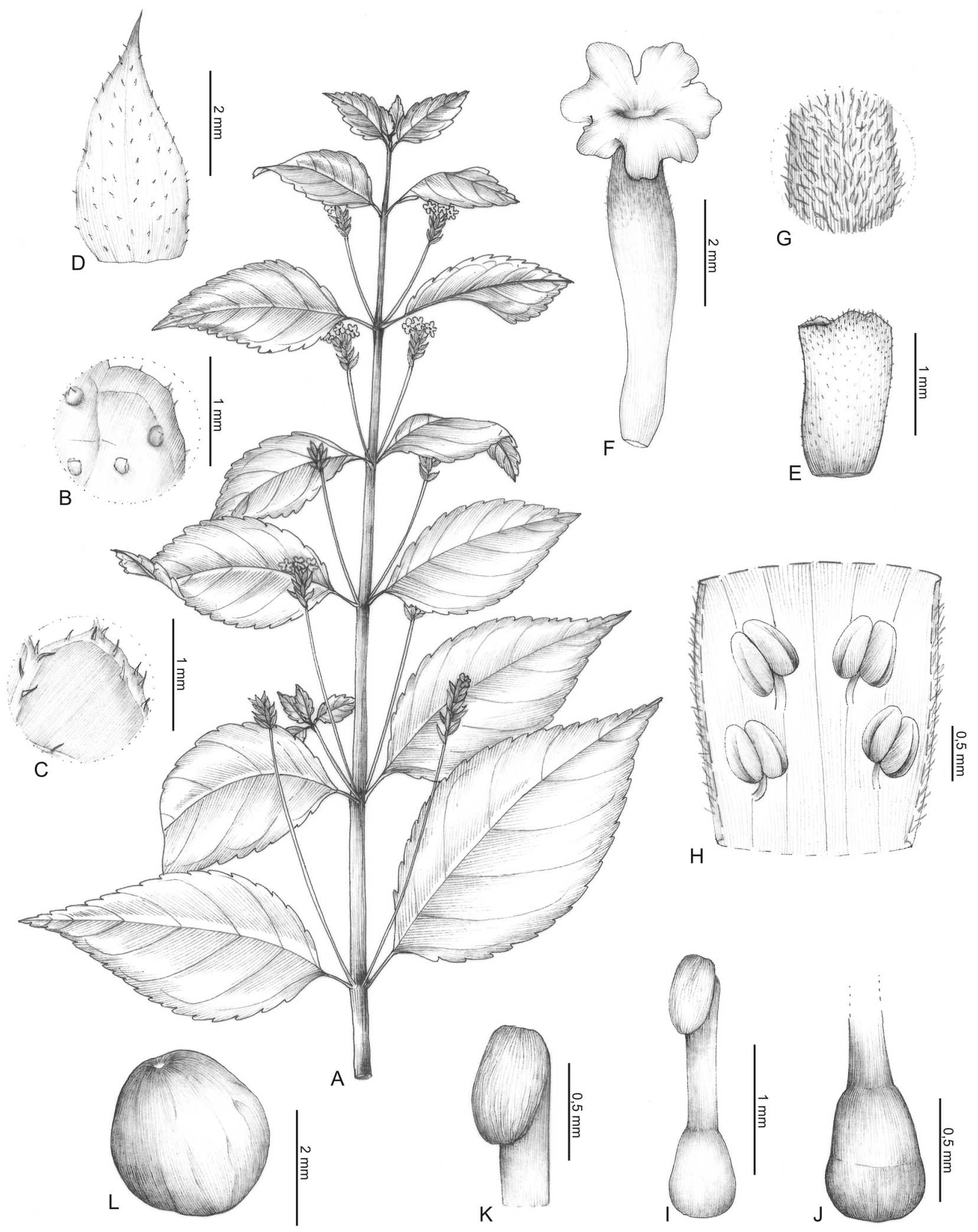

Figura 20. Lantana undulata: A- hábito; B- detalhe da lâmina, face adaxial; C- detalhe da lâmina, face abaxial; D- brácteas; E- cálice; F- corola; Gdetalhe do indumento da corola; H- detalhe do androceu; I- gineceu; J- ovário; K- estigma; L- fruto. (Pinheiro 1218 e Carvalho 3940 ). 


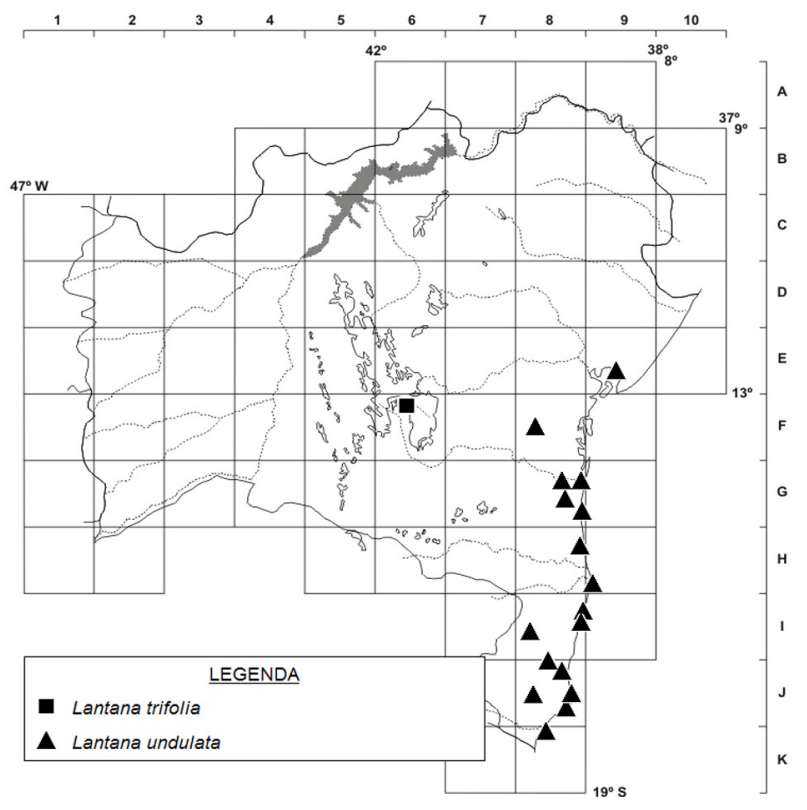

Figura 21. Mapa de distribuição de Lantana trifolia e L. undulata no estado da Bahia.
3903'W, mar. 1974, R.M. Harley et al. 17537 (CEPEC, IPA, K, P, RB); Itamaraju, abr. 1967, L. Castellanos 26415 (CEPEC, MBM); Mucuri, jul.1984, M.M. Santos \& J.C.A. Lima 112 (CEPEC, HRB); Picadas, ago. 1993, M.L. Guedes et al. s.n. (ALCB 26564); Porto Seguro, abr. 1991, G.L. Farias 423 (CVRD, K); Prado, 17¹1'S, 39²0'W, out.1993, W.W. Thomas et al. 10121 (CEPEC, K, NY); Santa Cruz Cabrália, maio 1994, M.L. Guedes et al. 3124 (ALCB); Texeira de Freitas, abr. 1992, G. Hatschbach et al. 57048 (K, MBM); Ubaitaba, abr. 1971, R.S. Pinheiro 1218 (CEPEC, NY); Una, mar. 1992, A.M. Carvalho et al. 3940 (CEPEC); Uruçuca, abr. 1978, S.A. Mori \& J.A. Kallunki 9886 (CEPEC, $\mathrm{NY}$ ).

Lantana undulata caracteriza-se por apresentar corola branca de comprimento maior que as brácteas.

\section{Agradecimentos}

Aos curadores dos herbários, que gentilmente cederam os espécimes, ao CNPq e CAPES, pelas bolsas às autoras, à Fapesb (PRONEM T.O. PNE 0020/2011) e CNPQ, pelo apoio financeiro ao projeto Flora da Bahia, e a Leandro Soares Lima, pela arte finalização das imagens.

\section{REFERÊNCIAS}

Atkins, A. 2004. Verbenaceae. In: K. Kubitzki \& J.W. Kaderiet (eds), The Families and Genera of Vascular Plants. Vol. 7. Springer-Verlag, Berlin, p. 449-468.

Atkins, A. 2005. The genus Stachytarpheta (Verbenaceae) in Brazil. Kew Bulletin 60: 161-272.

Lopez-Palácios, S. 1977. Flora de Venezuela - Verbenaceae. Talleres Gráficos Universitarios, Mérida.

Marx, H.E.; O'Leary, N.; Yuan, Y.; Lu-Irving, P.; Tank, D.C.; Mulgura, M.E. \& Olmstea, R. 2010. A molecular phylogeny and classification of Verbenaceae. American Journal of Botany 97: 1647-1663.

Silva, T.R.S. 1999. Redelimitação e Revisão Taxonômica do Gê- nero Lantana L. (Verbenaceae) no Brasil. Tese de doutorado. Universidade de São Paulo.

Sinha, S. \& Sharma, A. 1984. Lantana camara review. Feddes Repertorium 95(9-10): 621-633.

Souza, V.C. \& Lorenzi, H. 2008. Botânica Sistemática. Guia ilustrado para identificação das famílias de angiospermas da flora brasileira, baseado em APG II. Instituto Plantarum, Nova Odessa.

Troncoso, N.S. \& Botta, S. 1993. Verbenaceae. In: A.L. Cabrera (ed.), Flora de la Provincia de Jujuy. Instituto Nacional de Tecnologia Agropecuária, Beunos Aires, p. 1-117.

\section{Lista de Exsicatas}

Agra, M.F. 5857 (3), 5859 (4); Alencar, M.E. 505 (3); Almeida, J. 348 (3); Alves, M.L. 25318; Anderson, W.R. 37123( 3); Andrade, C.T. 1 (12); Andrade, L.L. ALCB 15933 (3); Arbo M.M. 5540 (4), 5641 (6), 7410 (2); Atkins, S. CFCR: 14194, 14359 (2), 14465 (6), 14641 (4), 14789, 14792 (2); Bastos, B.C. 96 (3), 126, 486 (4); Batista, C.R. 3 (3); Belém, R.P. 3644 (9); Berg, C. 946 (10); 977 (3); Bernd, R.B. 17 (3); Blanchet, J 138 (3), 534 (13), 1005 (11), 3136 (12); Bohrer, C.B.A. 6 (3); Brazão, J.E. 307 (5), 360 (12); Britto, K.B. 26 (4); Bueno, P. 23 (3); Cajaíba, A.F.F. 4 (12); Carneiro-Torres, D.S. 1 (8), 190 (12); Cavalcanti,. T.B. 2448 (7); Carvalho, A. 124 (3); Carvalho, A.M. 321 (11), 1911 (8), 1929 (3), 3940, 3941 (14), 3683 (3); 3880, 6946 (4); Carvalho, C.A.L. 33, 38 (4); Castellanos, L. 26415 (14); Castro, R.M 1097 (5); Cerqueira, J. 20 (5); Chautems, A. 150b (5); Conceição, A.A. 2474 (5); Conceição, A.S. 99 (10), 141 (3) 208; 217 (3), 698 (8); Conceição, S.F. 92 (2), 108 (3) 110 (3), 115 (5); Correia, C. 147 (3); Costa, A.L. 3577, 3580 (3), 3586 (9); Costa, B.M. s.n. ALCB 6989 (5); Costa, J. 12 (10), 72 (10); Costa, K.C.
74, 103, 232, 233, 242 (3); Curran, H. M. 212 (5); Döbereiner, J. 1461 (4); Duarte, A.P. 5920 (14), 5934 (3); Farias, G.L. 423 (14); Feldili, J.M. 185 (3); Fernandes, A s.n. SP 113034 (5); Ferreira, M.C. 713 (10), 987 (3); Folli, D.A. 1054 (12); Fonseca, M.L. 2440, 4020 (3); Fonseca, M.R. 345 (10), 1301 (4), 1315 (7), 1389 (8); França, F. 891 (14), 894 (5),1017 (6), 1096, 1104 (10), 1443, 1848 (3), 1625, 1796 (4), 1942 (9), 2082 (3), 2083 (5), 2084 (10), 2309 (4), 3053 (5), 3056 (9), 3298 (10), 3496 (5) 3551 (4), 3569, 3811 (9), 4077 (5), 4119 (2), 4237 (5), 4297 (6), 5007 (3); Freitas, I.S. (2); Funch, R. 82 (3); Ganev, W. 170 (6), 403 (3), 746 (6), 1457 (2), 3028 (6), 3094 (5), 3510 (6); Gehrt, A. 37227 (3); Gentry, A. 49937 (14); Geraldes, S.S. 9 (12); Giulietti, A.M. 1838 (4), 2327 (6); Gomes, D.J. 37 (3); Gomes, L. 3 (11); Gouveia, E.P. 65/83 (3); Grupo Pedra do Cavalo 258 (4), 401 (3), HUEFS: 948, 949 (4); Guedes, M.L. 292 (2), 1177 (5), 26610 (8), 2633 (3), 2808 (4), 3124 (14), 3274 (10), 5734 (6) 7008 (3), s.n. ALCB 26564 (14); Guillaumon, J.R. 79 (3); Hage, J.L. 240 (14); Hage, J.L. 1685 (12); Harley R.M. 5862 (10), 5949 (2), 
15027 (6), 16344 (2), 17478 (3), 17537 (14) 18072, 18239 (11),19465 (4), 20053 (6), 20935 (12), 21360 (5), 21362, 21404, 21536 (9), 21617 (3), 21658 (9), 21702 (1), 22111 (11), 22413 (12), 26441(4), 28541, 28542 (3), 53524 (6), 53603 (3), 53936 (2); Hatschbach, G. 46372, 55152 (3); Hatschbach G. 57048 (14), 62871, 63168 (11); Hatschbach, G. 47050 (9); Hind, D.J.N. 3147, 3233 (2), H 50278 (3); Irwin, H.S. 30686 (2); Jardim, J.G. 2810 (10), 2813 (5), 3511 (9), 3601 (1), 3431 (3); Jesus, J.A. 2135 (12); Jesus, J.X. 28 (3); Jesus, N.G. 131 (3), 406 (8), 959 (10); Jost, T. 72 (10); Lara, L. 4 (5); Lemos, R. 6364 (3); Lewis , G.P. 1968 (4); 20

Lima, J.C.A. 97 (5); Loizeau, P.A. 510 (2); Longa, C.M.O. 10 (5); Lutzelburg, P.V. 767 (3); Lyra-Lemos, R.P. 1863 (14); Mattos, G.O. 70 (3); Mattos-Silva, L.A. 1026 (8), 3212 (14), 3269 (3); Medeiros Neto, E.C. 19 (3), 62 (11), 63 (8); Melo, E. 963 (11), 974, 986 (6), 1090 (4), 1306 (2), 1306 (5), 1625 (4), 1677 (2), 1857, 1948, 2049 (3), 2062, 2075 (4), 2389 (8), 2730, 2758 (9), 2895 (13), 2914 (4), 2966 (3), 3038 (4), 3372 (2), 3581, 3607 (5); Mendes P.T. 4928 (5); Miranda, A.M. 108 (3); Miranda, A.S. 37 (14); Mori, S. 10360 (11), 10634 (14), 10635 (12); Mori, S.A. 9886 (14), 11848 (4), 14183 (8); Nascimento, A. 24 (4), 267 (11), 284 (5); Noblick L.R. 1699 (11), 1838, 2033 (4), 2037, 2127 (3), 2130 (10), 2244 (5), 2479, 2655 (3), 2811 (2), 3105 (4), 3145 , 3227 (3), 3444 (11), 3519 (2), 3613, 3619, 3635 (3), 3967 (5), 3971, 4346 (3), 4350 (4), 4557 (2); Noelma 29 (12); Nonato, F.R. 853 (3), 1026 (4); Nunes, T.S. 300 (3). 333 (4), 334 (3), 564 (5); Oliveira, A. 36 (5), 68 (2); Oliveira, C.M. 58 (12); Oliveira,
E.L.P.G. 731 (3); Oliveira, P.P. 17 (11); Oliveira, R.P. 40 (2), 281 (3), 300 (4), 350 (3); Orlandi, R.P. 343 (2); Pinheiro, .R.S. 1218 (14); Pinto, G.P. 30/81(3), 268/83 (5), 274/83 (14), 370/83 (10), 63/86 (9); Queiroz, L.P. 866 (11), 868 (8), 1027 (3), 1145a (4), 1145b (2), 1399 (8), 1484 (3), 1488 (5), 2511 (4), 3133 (5), 3137, 3233 (10), 4268 (2) 4673 (8), 5695 (2), 5781, 5841 (3), 5970 (1), 7731 (2), 9859 (3); Ribeiro, P.L. 69 (3); Ribeiro, T. 13 (8); Ribeiro-Filho, A.A. 196 (10), 167(3); Rocha, A. s.n. IAC 23269 (4); Rocha, R. 397 (11); Rodrigues, M.O.S. 1 (5), 11 (3); Salgado, O.A. 312, 346 (3); Salimena-Pires, F.R. 2303 (3); Salzmann, M. 425 (11), 426 (3), s.n. HUEFS: 42234, 42233 (11); Sant'Ana, S.C. 810 (14); Santana, W. (12); Santos Filho, O. 8 (3); Santos, A.K.A. 220 (11); Santos, E. 1973 (4); Santos, E.B. 97 (3); Santos, F.S. 459 (14), 836 (3), 841 (12), 850 (14); Santos, M.M. 112 (14); Santos, T.S. 3304 (3); Sellow, F. 42236 (12); Senra, L.C. 9 (5), 22 (4); Siber, B. 11502 (12); Silva, L.A.M. 827, 3269 (3); Silva, M.A. 1307 (6); Silva, M.M. 84 (2), 258 (5), 269, 279 (9), 394 (14), 536 (3); Silva, P. 48 (5); Silva, S.B. 240 (12); Silva, T.R.S. 19 (6), 20(11), 106 (9), 124 (2), 127, 143, 154 (9), 174 (6), 193 (8), 194 (12), 195 (10), 211 (3), 215 (2), 216 (12), 237 (13); Silva-Castro, M.M. 651 (5); Silva-Pereira, V. 5 , 45 (2); Sobrinho, J.P.L. 1500 (3); Sobral, M. 8425 (8); Soeiro, R. 13/88 (12), 90 (8); Sousa, A. 10 (12); Souza, E.B. 1033 (5); Souza, E.R. 459 (10) Souza, F. 458 (12); Souza, P. 10753 (5); Souza, V.C. 5405 (5); Stannard, B. 27371 (3), 50845 (2); Thomas, W.W. 10121, 11573 (14); Ule, E. 6993 b (4); Viana, B.F. 63 (11), 122 (12); Voeks, R. 598 (3). 